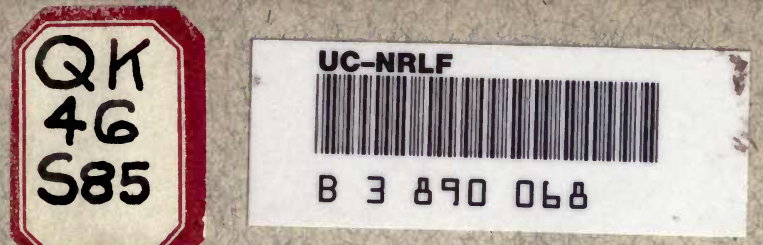




\section{BIOLOEX IIBRARY}

3ry्युम्ब

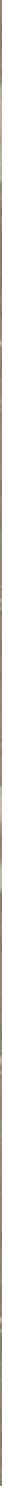




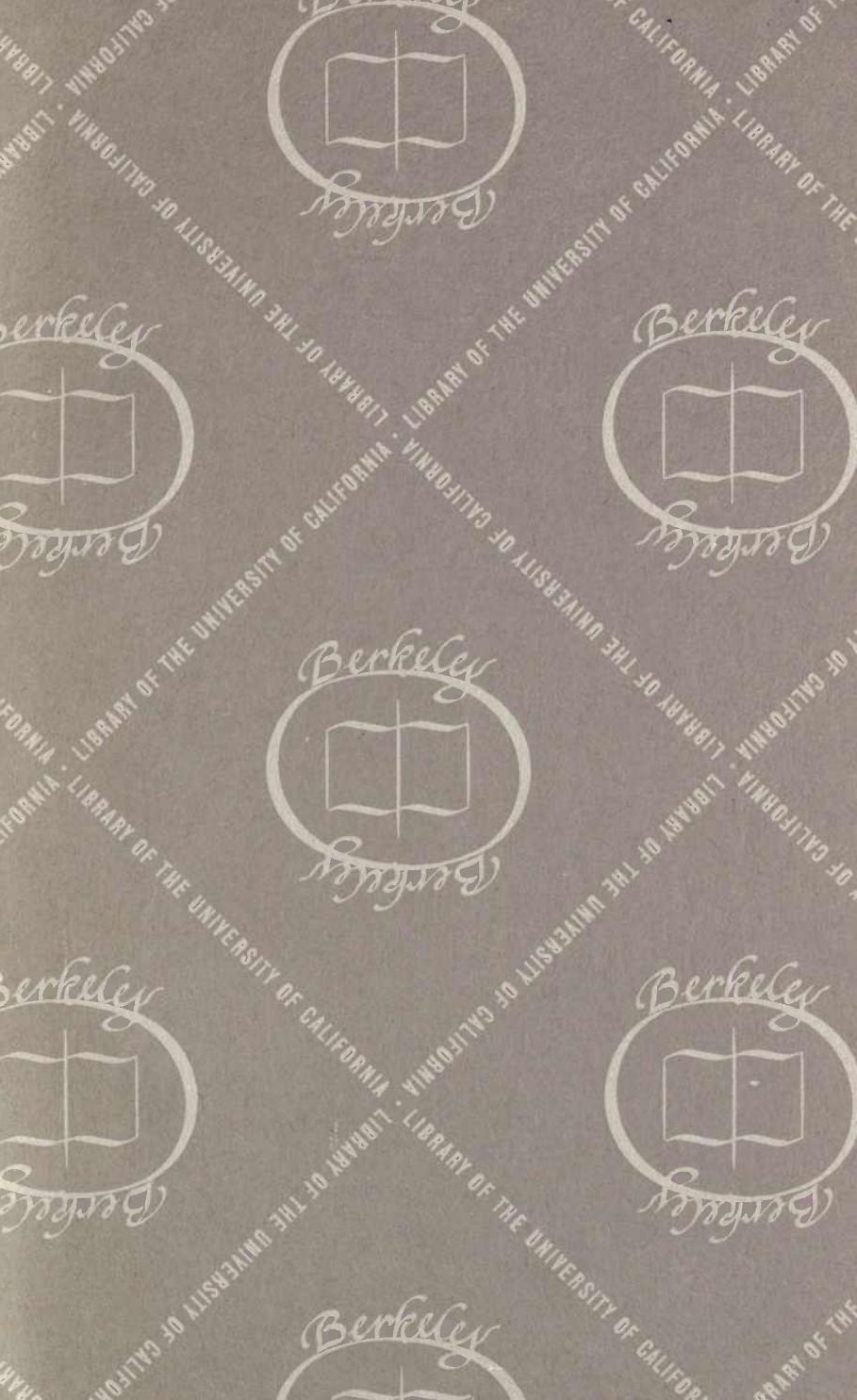





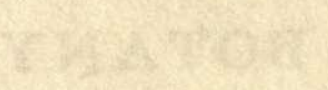




\title{
BOTANY (
}

\section{THE MODERN STUDY OF PLANTS}

\author{
BY MARIE STOPES \\ D.Sc. (London), Ph.D. (Munich), F.L.S.
}

AUTHOR OF "THE STUDY OF PLANT LIFE," "ANCIENT PLANTS," ETC.

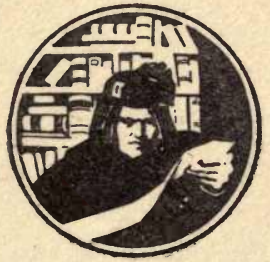

LONDON : T. C. \& E. C. JACK

67 LONG ACRE, W.C.

AND EDINBURGH 
BIOLOGY LIBRARY

G

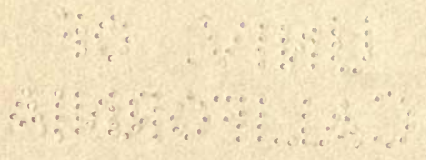




\section{GONTENTS}

grap.

PAGE

I. INTRODUCTION

II. MORPHOLOGY .

III. ANATOMY

IV. OYTOLOGY

v. PHYSIOLOGY

VI. EOOLOGY .

VII. PALAONTOLOGY

VH. PLANT BREEDING

IX. PATHOLOGY

X. SYSTEMATIO BOTANY

XI. CONCLUSION

SUGGESTED COURSE OF READING INDEX 



\section{BOTANY}

\section{CHAPTER I}

\section{INTRODUCTION}

IN our daily life we have no difficulty in distinguishing plants from animals, and we are also seldom in doubt as to the difference between a life-containing and an inorganic thing. It is true, of course, that at the extreme limits of the series, among the very simplest forms, it is sometimes difficult to separate plants and animals; but in most cases there can be no doubt as to which of the two great classes any thing or any creature belongs.

All the life in the world is embraced in one or other of the two great classes of Plants and Animals. Outwardly they appear so different from each other, but, as we shall see, they have a wonderful unity in the fundamentals of their structure. The science of the study of life is called Biology, but in these days, when so much detail has been accumulated and stored in books, it is no longer possible for one mind to grasp the whole subject. It has been divided into the two natural divisions of Botany, the study of the plants, and Zoology, the study of animals.

It happens that man is an animal, consequently the scientific study of his body should be the work of the 
zoologisto. So much, however, is known about man, and so much more knowledge is eagerly wished for, that the study of this single animal has become a science in itself, of which there are many brancheshuman physiology, pathology, \&c. This has tended to split up the science of "Zoology," and this tendency has been further encouraged by the fact that there are such extraordinary numbers of some animals, e.g., the insects, that their study forms a special science of its own called Entomology.

The science of plant life is much more united, and Botany includes all the sides of the study of all plants, with the exception, perhaps, of the bacteria which have a science of their own. In many ways this unity in botany is a great advantage, for none of the branches of any science are really independent of each other, and it is impossible to study one-let us say, for example, the physiology of plants - without a knowledge of the others, and, in this instance, of anatomy and cytology.

Nevertheless, even in botany, and particularly the botany of this century, the various problems in the different branches of the subject have to be attacked in such different ways, that it is almost impossible for one man to make discoveries in more than one or two restricted fields. In each part of the subject the instruments used, the language employed, and the methods of attacking the problems are all so distinct from each other, and so elaborate, that they demand an almost lifelong study. This is parallel to the case of music, which is in itself all the harmony of one order of sweet sounds, and yet there are but few musicians who have complete technical control of more than one or two instruments. In the case of science and its branches, the worker has not only to attain personal control of 
his tools, but he has to keep in touch with all the work and discoveries of the others who are engaged on investigations akin to his own, and this necessitates an amount of reading that rivals the columns of print poured out by the daily press. Every country that possesses universities and learned societies is rivalling every other in the production and publication of additions to scientific knowledge. One who is himself adding to this must be aware of what all the others are doing, lest he repeat work already done, or lest he lose the help and inspiration that other work may be to his own.

We see, then, in the modern science of botany a philosophic whole, which is only to be attained by the combination of the results of a number of separate lines of work, each of which requires special technical study. In the following chapters the more important of these branches will each be dealt with shortly. In such small compass it will not be possible to give very many facts, but the text-books are full of them; it will not be possible to go into very abstruse discussions-the learned Transactions are full of them; but it will, I hope, even in so few words, be possible to illustrate the attitude of the workers in each branch of the study, and to indicate the field in which they labour. Then at the end of the book the reader should be in a position to see for himself how it all hangs together and bears on the one great problem in biology-the evolution of life. 


\section{CHAPTER II}

\section{MORPHOLOGY}

THE study of Morphology is the study of the form and external appearance of the plant's body. Just as there is unity among animals, and we recognise legs, eyes, tails, and the various parts of the body in many different guises in the different species of animals, so there is a unity of organisation among the higher plants, and their bodies are composed of a limited number of parts which belong to distinct categories.

The body of a typical member of the higher plants is oomposed of four elements, viz., Roots, Stems, Leaves, and Sporangia. The flowers, which at first sight appear so distinct, are in reality composed of modified leaves.

The extraordinary variety of plant structures and all their beautiful and remarkable forms are simply modifications of these four elements. Each of them has its characteristic structure, and its normal functions, and in most cases, however the parts are modified, they remain recognisable. Some parts may be modified out of immediate recognition, as we shall see in a moment, but careful study will reveal their true nature.

If you pull up any common weed, such as a Campion or a Poppy, you will notice that the root and the stem merge into one another, but that there is a contrast between them in colour and form as well as in position. The leaves are attached to the stem, and never to the 
root, and they are typioally green expanded surfaces of different shapes according to the species.

The three fundamental elements-roots, stems, and leaves-are all that compose the vegetative plant, which, under favourable conditions of nutriment, may continue to grow for a long time. Some of the very large Monocotyledons, for instance, live the whole of their long lives as vegetative plants, and then at the end of a lifetime produce a great number of reproductive organs and die.

The fourth set of organs-the reproductive-are known in their simplest terms as Sporangia. The "flowers" which we associate with most of our common plants are composed of the essential sporangia and a number of modified leaves, which form altogether structures of extraordinary complexity and variety. In many cases the colours, designs, and positions of the modified leaves which form the flower have a very definite relation to the insects which visit it and do an important work in carrying the pollen which is produced in the sporangia (pollen sacs) from one flower to another. But this will lead us to another aspect of the subject. Let us for a moment consider the four essential elements of the plant's body.

The Roots generally ramify in the soil and live altogether underground; this is, however, a physiological rather than a morphological character. Morphologically the principal difference between roots and stems is that, though the roots and the leaves both spring from the stems, the roots themselves do not bear leaves. Some plants have underground stems, which are often extremely like roots in their external appearance, but on them one can generally find traces of the reduced leaves in the form of small brown scales, which 
show that the root-like organ is really a stem. In their internal anatomy the two organs differ essentially, as we shall see in the next chapter, and there are cases of modified leaves and stems which have departed so far from the normal that the external morphology gives no clue to their real nature, and then the anatomy alone can determine to which category each belongs.

The typical root is a colourless or brown series of circular or flattened branches. It is never broad and expanded like leaves, though in some cases, e.g., epiphytic orchids, it may be green. The main root is the continuation of the original primary root of the seedling, which has subdivided indefinitely with its growth, and this is often supplemented by further roots which arise adventitiously on the stem wherever they are needed, either in the soil, in the air, or in water. A sprig of Mint or Ivy left in a jar of water will often show the white tufts of adventitious roots springing out of the base of the stem. The great prop roots of the Mangroves and some of the tropical species of Ficus are woody and covered with bark, so that it is hard to find any external feature-other than their position-by which to distinguish them from the stem-trunks.

The Stems which support the leaves and connect them with those sources of food supply, the roots, are generally upright, cylindrical, and branched in the air. They have, however, an infinite variety of form, and range from the sturdy Oak to the slender climbing Convolvulus, from the great pudding-like Cactus and swollen masses of the Potato to the slender threads of the water Ranunculus; and from the root-like Solomon's seal running underground, to the contracted stem of the ærial Orchid perched aloft on the branches of other plants, so that it never comes down to earth. Normal, 
ærial stems are generally green when they are young, and as they age they put on a coating of thick bark and cork outside their woody growth. There are stems,

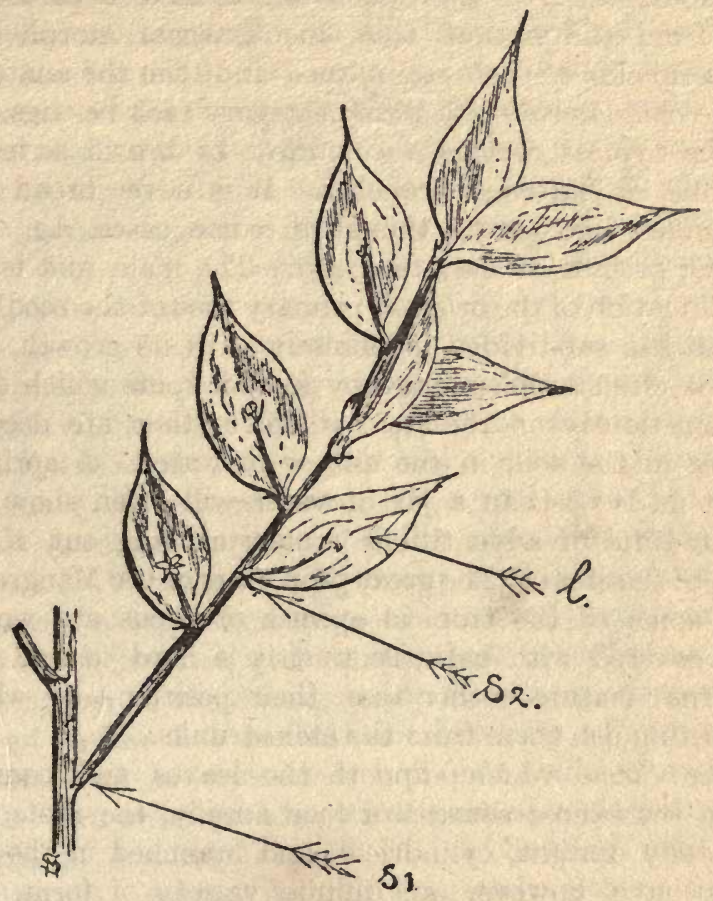

Fra. 1. - Part of a twig of Ruscus (the Butcher's Broom) showing the leaf-like modifled branches $l$, which are attached to normal stems. Deneath each is seen the scale-like realleaf, 82 , in whose axils the branches arise. Simflar scales, 81 , subtend ordinary branches.

however, which never have the appearance of true stoms, but which simulate leaves. Perhaps the best known example of this in the British flora is the Butcher's Broom (Ruscus). A branch of this plant appears to 
be covered with simple oval dark-green leaves just like any other ordinary shrub. But if you examine these "leaves" closely you will see that they have just beneath each of them a small scale-like structure. This is the true leaf, and the big apparent leaf is a flattened branch coming in the axil of the reduced leaf. The stem nature of these apparent leaves becomes obvious at the time of flowering. Then a little flower or tuft of flowers arises in the middle of its surface. Text-figure 1 shows a sketch of a Ruscus branch with its false leaves that are really stems.

The Leaves are of all the organs the most subject to variation, and their modifications are endless. The normal foliage leaf is flat and expanded, its outline may be quite simple or deeply cut and elaborately shaped. Commonly there is a leaf stalk which attaches it to the stem. Foliage leaves are green because they contain the green substance which is such an essential factor for the nutrition of plants (see Chapter V.). Leaves are modified, however, to serve innumerable purposes, and, according to the functions they perform, so do they become changed-sometimes almost out of recognition. They may be rendered functionless and useless by the position in which they find themselves, as, for instance, when the stem bearing them runs underground. They are then reduced to the merest remnant of scales, brown or colourless, and thin of texture. Sometimes in the underground position they take on a new function - that of storage. Where they cannot produce food they adapt themselves to store what the other air leaves have produced, and this we see in the bulbs of Tulips and Lilies and Onions. The fleshy part of the "bulb" is oomposed of the modified leaves filled with the stored food. In many trees we find modified leaves on the 
same branches that bear normal ones. For example, the hard brown scales which surround and protect the delicate foliage leaves in the bud are themselves simply leaves which have been modified for this purpose. In some buds, for example the Horse Chestnut, you can

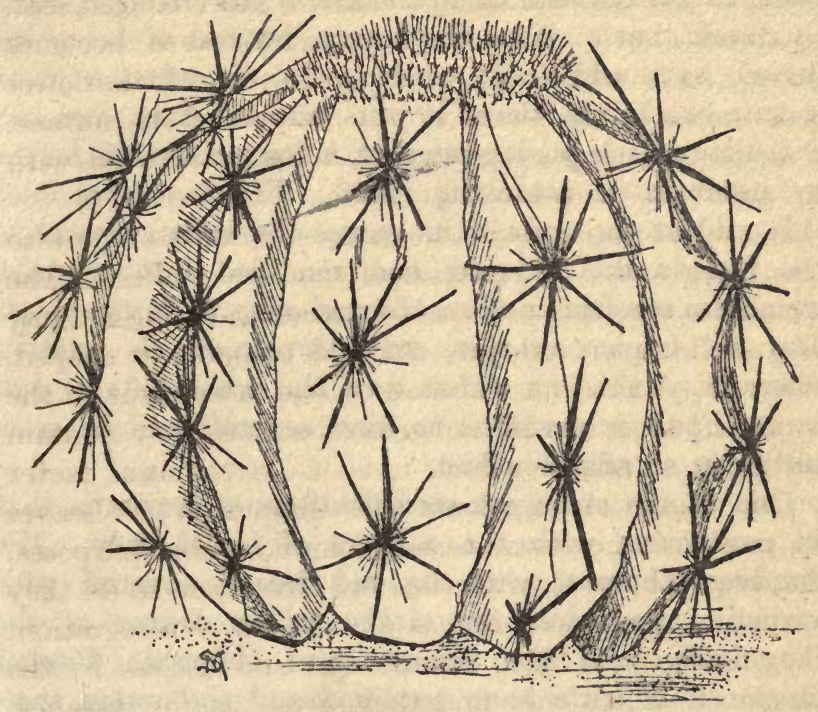

FIG. 2.-A spiny cactus, showing the rounded fleshy stem which is green, and performs the food assimilation instead of the leaves. The true leaves are modified into hard spines.

find a gradual transition from the outermost brown hard scales to the inner ones, which are soft and green.

In some plants the leaves are all modified and hard, and the stem does the work of assimilating. For instance, in the Cactus the leaves are all reduced to needle-like spines, but the stem is soft and fleshy and green-coloured, and manufactures all the food. The 
rounded fleshy mass of the stem exposes much less surface for evaporation than would the laminæ of ordinary leaves, and the plant is thus able to inhabit very arid regions.

A great contrast to the Cactus, with its pudding-like stem, is the delicate Creeper that is not strong enough to stand alone. Here the leaves, instead of being reduced, have additional work to do, for when a plant economises in the tissue it puts into its stem, and has a slender axis requiring support, it may call on its leaves to assist it in attaching itself. The Sweet-pea does this, and at the ends of its compound leaves several of the leaflets are reduced and modified into tendrils, which are sensitive and motile and cling to any support. The well-known creeper, the Ampelopsis, is another example of this, in which case the whole of one leaf in each pair is modified to form several tendrils, each ending in an adhesive disc.

One of the strangest modifications of leaves is that in connection with the capture of insect prey. The Sundew (Drosera) with its red leaves covered with sparkling tentacles, the sickly yellow leaves of the Pinguicula, and the strange and elaborate Pitcher plants of all sorts have modified and elaborated their leaves to produce traps for the insects they capture and use as food.

Though the leaves naturally are supported by the stem, there are not wanting cases where the leaves have become the support of the whole plant, as, for instance, the great Stag's-horn fern, which is attached to tree trunks, and, with its large shield-like leaves, forms a bracket which eatches fragments of soil and holds the water, forming a kind of flower-pot in which the roots ramify. Even more specialised " flower-pots " are 
known in the tropical, rock-inhabiting Discidia. In this plant one leaf of a pair forms a bag, much like that of a Pitcher plant, in which the adventitious roots from each node are contained.

Such extreme modifications are unusual, but every normal plant has various kinds of leaves, and we must now turn to the modified leaves which unite to form, with all their infinite varieties, what we call the flower.

The essential parts of the flower are the sexual cells, but, like the individual tissue cells, these are very minute, and so, for their protection and assistance, a number of leaves have become particularly modified on a given plan which, in its essentials, is common to most flowers.

The outer leaves of a flower are protective, and these are generally green or brown and of strong texture. In most of the higher plants they have a definite number, often three, four, or five. Within them the next set of leaves is generally more brilliantly coloured and of more delicate texture. To this special series of leaves the name corolla is given, and the individual leaves are called the petals. Their work is entirely different from that of ordinary leaves, and, while it is partly protective, their use is largely to make the flower attractive to the insects which come (or used to come in the past) to carry the pollen which effects cross pollination. We next come to the more important "leaves," which are reduced in general to small stalks, bearing the male sporangia, called the pollen sacs. The Sporangia belong to a distinct category of organ, and though they arise on the modified (and in some families on the normal) leaves, they are distinct from them in just the same sense that the leaf is distinct from the stem that bears it. Indeed the distinction is more 
fundamental when one goes back to the origin of things, for the simplest kinds of plants have only two kinds of cells, the vegetative and the sporangiate.

These reduced leaves of the flower and their spore sacs are called stamens; the pollen grains, or spores which they produce, contain the male nuclei. The reduced stalk-like "leaves" of the stamens have a great tendency in many flowers to enlarge and become petal-like. The large flowers of the Rhododendron commonly show many intermediate stages between ordinary petal leaves, through half reduced petals with one or more anthers, to the normal stamens. The "doubling" of Buttercups, Cherries, and such flowers is due to the greater part or all of the stamens becoming petaloid. When the doubling is complete the flower cannot produce any pollen of its own, and must either be pollinated from the single flowers or remain sterile.

We have spoken of the production of the male nuclei in the pollen, and this, of course, presupposes the existence of a female cell with which it can fuse. These female cells are produced in "ovules," which are contained in one or more cases or carpels lying in the centre of the flower. These structures are exceedingly complex, and the details of their morphology require much study, and are still the subject of investigation and discussion. There is, however, no doubt that the closed cases or carpels which contain the ovules represent a leaf in which the edges have rolled over and joined up to form a little bag-like structure. This may be entirely closed, or may tend later to split open again, as it does in the Larkspur, for example, when the seeds are ripe. The unfertilised seeds or ovules containing the eggcell develop on the inner edges of the carpel leaves, and are thus protected by the closed bag they form. 
In many details the ovules correspond to sporangia, but they are not simply sporangia, and they have added to them several coats and inner tissues which no simple sporangium has. The egg-cell, however, is the fundamentally important feature in them, and it is with this cell that the male nucleus fuses, and it is for the sake of bringing these two cells together, and protecting the young embryo formed after their fusion, that all the complexity of the flower has been developed. How complex it is, and how ancient its history, one can only realise after studying the fossil types which have gradually led up to it.

Some of the fossil seeds from the Coal Measure period are even more complex than those of the present day.

We have now noticed shortly all the organs of a plant. It is likely that a reader will immediately think of fruits and seeds which appear such distinctly characteristic structures. They are, however, but modifications of the parts we have already mentioned. The seeds are but the ovules enlarged with the growing embryos, in their tissues storehouses of food, and with the outer ovular coats hardened. The fruit, whether fleshy, winged, or plumed, is a further growth and modification of the carpel leaves or of several carpel leaves fused together, or of the carpels with some of the other flower-parts adhering to it and ripening with it, instead of being shed as soon as the flowering was done. The only new thing in the fruits and seeds is the embryo, and that begins a new cycle and belongs to a new generation. It is composed, however, of the fundamental vegetative organs-a root, a stem, and the first leaves. These organs are produced in miniature in the seed, and then they lie there for a long resting period in most plants. 
The germination of the seed is the waking of these same organs to life and further growth. In the growth and development which follows the germination of the seedling there are many features of considerable morphological interest. The young plant often tends to repeat in its own life history some of the stages through which its species passed as a whole in its evolution. Thus we find in the development of plants with divided, complex leaves that the first three or four leaves of the seedling are simpler, and it is only as it grows that it attains the elaborate adult foliage. Plants, too, which have specialised stems or elaborate structures to replace ordinary foliage, will generally have a much simpler and more normal structure when they are very young. The study of seedlings is, therefore, a very useful factor in attempting to elucidate some of the morphological problems.

So far we have considered only the body of the higher plants, in which, though there is infinite variety of detail, there is a uniformity of plan throughout. Among many of the lower plants we find the vegetative body composed of the same set of organs-root, stem, and leafas in the case of the higher plants. Further comparison is rendered more difficult by the fact that the alternation of generations, common to nearly all plants, is in them expressed in terms of two distinct individuals, and a small green plant (known as the Prothallus) bears the sexual cells of the large, leafy fern. The prothallial plant is produced from the spores of a simple kind which are often borne, not on flowers, but on the ordinary foliage of the vegetative plant. All our common ferns have this character, and the brown marks on the leaves are clusters of small sporangia, while the little prothallial plant they produce is gener- 
ally entirely neglected and overlooked owing to its minute size. The mosses also have an alternation of generations, but in their case the reverse is true, and what we know as the moss plant is the prothallial generation, which has elaborated itself so that it has much the appearance of a leafy plant, though it is so different in its origin from the leafy plants of other groups.

In the algæ we find the plant body represented by simpler structures. The whole algal body is often called a thallus, and this has regions which correspond more or less closely to root, stem, and leaves in the more elaborate and larger of the seaweeds. In most algæ, however, there is little differentiation among the cells, and in the simple hair-like forms so common in the fresh water ponds and streams, there are only green vegetative cells and reproductive cells with no modification into true "organs."

In the fungi we get also a very simple plant body, generally like that of the thread-like algæ. Sometimes many of these filamentous cells intertwine to form quite large and apparently complex bodies, the toadstools for instance, but the plants have not truly differentiated organs.

It is interesting to notice how a number of the higher plants have degenerated and lost the differentiation of their parts. For example, the Dodder (Cuscuta), which grows with such deadly success on the Clover and Furze, appears to have lost all differentiation of stem, root, and leaves, and has become a mere tangle of fine pinkish fibres, which attach themselves to the stems of other plants and draw all nourishment from them. Its flowering, however, it must do for itself, and the parts of its flowers, which appear in relatively 
large clusters on the thin stems, are quite normal. One of the most interesting cases of a reduced structure is the plant body of the giant-flowered Rafflesia. This has the largest flower in the world, and it appears to have no vegetative body at all! That is because it is so completely parasitic that it gets the whole of its nourishment from a host on which it preys, so that it can afford to reduce its own vegetative body to the minimum, viz., a series of white fungus-like threads which are enclosed in the body of the host. In this plant roots, stems, and leaves are all gone except for the modified leaves of the flower. 


\section{CHAPTER III}

\section{ANATOMY}

WHILE the morphologist deals mainly with the external form of the organs of the plant's body, the anatomist inquires into the internal structure of those same organs, and investigates the arrangement of the tissues of which they are composed.

The plant body, like that of the animal, is built up of a number of different tissues, each of which has its function to perform in the economy of the whole organism. In the animals there are bones, muscles, nerve fibres, fat, and so on ; in plants there are wood, ground tissue or parenchyma, strengthening tissue or sclerenchyma, and so on. The physiological functions performed by each of these sets of tissues is generally the same throughout the whole animal and plant kingdom. Thus the bones, for example, whatever their shape or arrangement, form the support of the body, and to them the muscles are attached; the nerves, whatever their plan of distribution, are the channels through which stimuli and nervous messages are passed. In plants, whatever its structure, the wood serves as the channel for the conduction of water; and the sclerenchyma, wherever it may be placed, is there for the purpose of strengthening or protecting the organ in which it develops. Hence, though it is neither wise nor possible to divorce entirely the study of anatomy from that of 
physiology, the main work of the anatomist deals with the tissues themselves, and concerns itself with their individual characters and the comparative study of their development in the different orders of organisms.

The plant body is composed of five principal kinds of tissue. These are the Epidermis, or skin, with its hairs and other minor developments; the Parenchyma, forming the general ground tissue of the plant, with a number of minor modifications; the Sclerenchyma, or thick-walled strengthening tissue; and the vascular tissue, which is of two kinds, viz., the Wood, which is thick-walled, and conducts water and also helps to strengthen the plant, and the Bast or Phlœm, which forms the channel for the passage of the elaborated food-stuffs. For the higher plants, although there is much specific variety, there is a characteristic plan for the arrangement of these tissues in each of the organsroot, stem, and leaf.

In roots there is no true epidermis, but the outer cells of the young root are extended to form long hairs with thin absorbent walls. The parenchymatous ground tissue forms the main mass of the root, and the vascular tissue is a compact, central strand. In most roots there is no pith, and the wood forms a solid mass in the centre with groups of the phlœem outside it. This cylinder is shut off from the surrounding ground tissue by a specialised sheath, which is generally much better developed in roots and in the lower plants, such as ferns and lycopods, than it is in the other organs of the higher plants, though it is sometimes clearly marked in their stems.

Stems have an epidermis while they are young, and this protective layer is replaced by an ever increasing secondary coat of cork as they increase in size. The 
ground tissue parenchyma may be modified into several kinds of cells for different purposes, and in young stems, which are green, the outer layers of the parenchyma usually contain minute green grains, the chlorophyll granules which play such an important part in the manufacturing of food. Often mixed with the parenchyma, in regular strands or groups, are thick-walled sclerenchyma cells, and their position in the stem is almost always that which is mechanically most advantageous. In stems there is generally a pith of soft parenchyma cells, and round that the vascular tissues are arranged in groups, each group composed of a strand of wood and a strand of bast. As the stem grows these separate strands of vascular tissue are joined to form a ring by secondary formations of wood and bast. Instead, therefore, of the central, solid strand of vascular tissue, as in the root, the stem is characterised by a hollow cylinder which is formed round a central pith. In some few stems of the higher plants, outside this cylinder an endodermis sheath like that in the root can be seen, and this is a fact which is of much theoretical importance.

There are many views as to the real meaning and origin of the woody cylinder, and the one which seems to be best supported by facts considers the hollow vascular cylinder to be the descendant of a solid strand not unlike that in the root, the central cells of which lost their character as wood cells and became simple parenchyma. The stems, which are preserved for us as fossils, seem to support this view, though at first sight it may sound rather far-fetched to say that the cells of the parenchyma on one side of the vascular strands have a different value from those on the other side of the same strands.

Probably one of the most powerful influences in the 
development of the wood on these lines was the mechanical advantage which was thereby gained, for, with the same number of thick-walled wood cells, a stronger column is produced when it is in the form of a cylinder than when it is solid. The wood cells in the stem have not only to conduct the water current to the leaves,

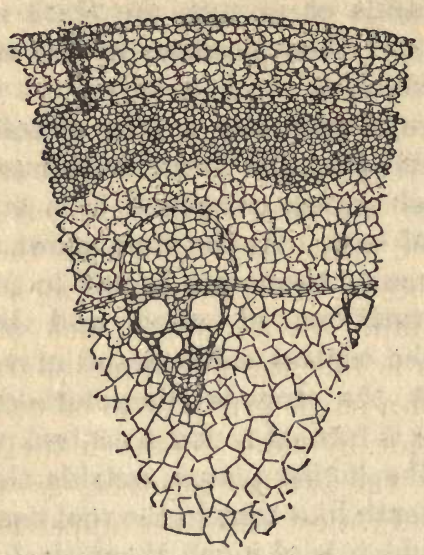

FIG. 3.-Transverse section of part of a stem of Aristolochia, showing the different kinds of ground tissue and vascular cells. The four largest cells in the centre are wood vessels, and the narrow layer of cells just behind them, is the cambium layer which gives rise to the new tissue year by year.

but have also to play a large part in making the stem strong enough to stand upright.

As the stem gets older the ring of secondary wood and bast increases greatly, and in perennial plants solid rings of wood are added year by year which soon dwarf the original primary groups of wood, and they cease to function after a time. In trees and woody shrubs the formation of the secondary zones of wood increases largely, and they become the principal feature in the trunk. 
The formation of rings of secondary wood takes place also in roots, so that when they are very old, and the inner tissues are crushed, it is not easy to disguish them from stems.

The primary structures, however, are easily distinguished, and when there is any doubt from the external morphology alone as to whether any organ is a root or a stem, a section showing the internal tissues will establish its nature.

The leaf, with its flat expanded surface, differs from the stem and root in having a bilateral and not a radial symmetry. In a typical dicotyledonous leaf the single vascular strand which runs out from the stem into its petiole branches in one plane to form a complete network like a fan. Each finer branch of the vascular strand in this is like the one from which it arose, and is composed of a single group of wood cells and a group of bast cells side by side. Between the meshes of this fan, webbing the whole together, is the soft-celled parenchyma. In most cases the upper layers are more closely packed and composed of more regular cells than those on the lower side, and generally all of them contain numerous green granules of chlorophyll. Enclosing and protecting this web of tissue on both sides is an epidermis. In many cases, particularly in the tough leaves of plants which grow in hard conditions, there are strengthening bands and props of sclerenchymatous tissue arranged to great mechanical advantage.

To the theoretically minded anatomist, and him who concerns himself with the phylogeny of plant structures, the greatest interest lies in the woody tissue. Not only is this easier to recognise and stain in living plants, but it is better preserved in the fossils than the softer cells, 
and has more character; while the other tissues seem to group themselves round it. It is to the plant's body what the bony skeleton and the arterial system combined are to the animal. It is thus not surprising that most work on plant anatomy treats principally of the woody cylinder.

What we have considered so far has been the vascular arrangement in the highest and most important family of plants, the flowering plants. In the lower families, both living and extinct, there are many other types of arrangement. The study of anatomy, therefore, bears on systematic botany, for the constant internal characters of the organs form reliable criteria for the separation of the different groups.

The outstanding features in the anatomy of the other principal groups of plants is as follows:-

The Gymnosperms (the pine-tree group) have a general structure similar to that of the Dicotyledons. Their wood differs, however, in the character of its uniform cells and in the pitting of their walls-a point we have not yet considered. They have a hollow primary cylinder with secondary zones of wood, quite similar to those in the flowering plants.

The Ferns, as they are now represented by the living species, are very different in their stem anatomy from these higher plants. In the first place, the primary organisation of their stems shows great variation in type in the different species. Yet the majority agree in having a number of separate strands, each organised like that of the root of the higher plants in so far as it has the wood in the centre with the bast surrounding it, and that each such strand is shut off from the surrounding parenchyma by a specially organised sheaththe epidermis. In a few ferns a single hollow cylinder 
is arranged on this plan, but in most there are several strands, and in many ferns the number of anastomosing strands is very large. In none of the living ferns are these primary strands united by any secondary growth of woody tissue. In the Lycopods the arrangement, though with individual peculiarities, is much like that in the ferns. So long as only living forms were studied, it was thought that the formation of secondary wood was a character only developed in the Gymnosperms and the flowering plants. Since the anatomy of the fossils has been studied, however, the remarkable fact has come to light that in the early and extinct forms of the ferms and the Lycopods, and even of the Equisetaceæ, secondary wondy tissue was developed in considerable quantities, and apparently on the same plan as is now found in the Gymnosperms. Their primary structures were like those of their living representatives, and quite unlike the higher plants. It is almost universally true that the primary structures of the plant are the truest guides to its affinity. The development in time past of the secondary wood in the Lycopods and other extinct Pteridophytes was at a time when they were among the largest tree-like forms of plants then extant. To support their mighty shafts and to supply their crown of leaves with water it was necessary to have additional woody tissue, which was developed in the most straightforward and simplest way in radial rows of cells. That Lycopods to-day do not develop such wood is doubtless due to the fact that they do not grow to such a size as to require it. But, when we ask why we do not now find them growing to such a size, we have left the province of anatomy and entered the philosophical field in which uncertainty still reigns. In the families below the ferns there is little that greatly 
concerns the vascular anatomist. The Mosses have but little differentiation into true tissues, though the wellknown genus, Polytrichum, has something corresponding to wood and phlœm cells.

The Algæ have no differentiation into true tissues, and only some of the largest of them, the Laminarias, show anything approaching the vascular cells of the vascular plants. In them there are zones of elongated cells with sieve-like plates between which distinctly resemble some of the bast cells in higher plants. The thread-like algæ and the fungi are simply composed of slightly differentiated cells which are fundamentally parenchymatous. For anatomical interest, then, we must return to the Pteridophytes and the higher plants.

From a study of the present-day ferns and the many fossil genera of Pteridophytes and that extinct group, the Pteridospermæ, it appears that a great many varieties of arrangement of the woody tissues have been attempted by plants. Many of these were much more complex than the simple hollow cylinder which is now found in the most successful and highest types. It appears almost as though the present simple type of structure were the result of reduction from something more cumbersome. The remnant of the endodermis, for example, which is found in some Dicotyledon stems to-day, is one of the clues that suggest this. Further, while it is out of the question in the present state of our knowledge to fill in the gaps in a direct series of descent, it is yet possible among the fossils of different families to show a conceivably parallel series in which the simple hollow cylinder of wood is connected with forms which had a solid central mass of wood, and, again, with others in which the pith was beginning to be formed in the middle of it. In the anatomy of all plants the rela- 
tion of the leaf strands to the vascular tissue of the main stem is a very important factor. In the modern higher plants the primary vascular strand passing up the stem passes directly out to the leaf stalk, so that the leaf strands and those from the stem are the same and form one system. In some of the lower plants, and in many of the fossils, this does not appear to be so, and it is possible that in the early forms the stem had a system of vascular strands of its own which helped to complicate matters for those who theorise. 


\section{CHAPTER IV}

\section{CYTOLOGY}

Tre anatomist, as we have seen, deals with the cells of the plant as they are grouped in tissues. To him the tissues (which are themselves composed of numerous cells) are the units with which he works. The cytologist deals with the ultimate unit of the plant body - the individual cell.

The body of a plant, like that of an animal, is ultimately composed of innumerable minute cells, which in the plant are each enclosed in a cell wall, and, together, they form a kind of honeycomb. The differences between the cells of the various tissues are principally. differences in the nature of their cell walls. Within, the fundamental living cell is extraordinarily uniform throughout the whole plant world. And even more remarkable is the likeness between the cells of plants and animals. In their fundamental and essential features, particularly at that critical time of division and reproduction, the likeness between the plant and the animal cell amounts almost to an identity. This branch of botany and this branch of zoology still remain under the old heading of biological science, for it is impossible to go deeply into cytological work without using both plants and animals as illustrations of fundamental facts.

The typical cell consists of a mass of protoplasm, with a central kernel-the nucleus; in plants this is 
almost always enclosed in a cell-wall of definite shape. Individual cells are very seldom large enough to be seen with the naked eye, though egg cells are in some families large enough to be recognised, and in some cases fibres and hairs several millimetres or more in length are composed of a single cell. In general, however, the study even of the grosser features of cells can only be undertaken through the microscope. To see the finer details. an exceedingly high power of magnification is required. To separate an individual living cell from the rest in a tissue is not easy, and yet for examination under high magnification the specimen must be exceedingly thin; even two of the smallest cells lying on the top of each other are too opaque for microscopic examination, consequently mechanical means are employed to cut thin sections of the tissues. The material to be examined is killed and "fixed" by some chemical solution which quickly penetrates to the finest ultimate structures in the cells, so that they remain as nearly as possible exactly as they were when alive. Many hundreds of sections may be cut from an object that is being studied, and the course of the life processes is reconstructed from them. Thus it happens that the motions and behaviour of the nuclei, for instance, though described as if from observations made on a living specimen, are seldom based on actual observations, and our knowledge of them is reconstructed from innumerable fixed sections.

The first glance at a parenchyma cell shows that the mass of protoplasm within its wall is finely granular, and that in it there is a darker mass, also granular, which is often found in a somewhat central position, and is called the nucleus. The nucleus is the most vital part of the cell, and its elaborate behaviour has 
attracted much study. What the wood is among tissues to the anatomist, that the nucleus is to the cytologist-the principal object of his research. Before we turn our attention to the nucleus, however, it is well to notice that in the protoplasm are a number of other

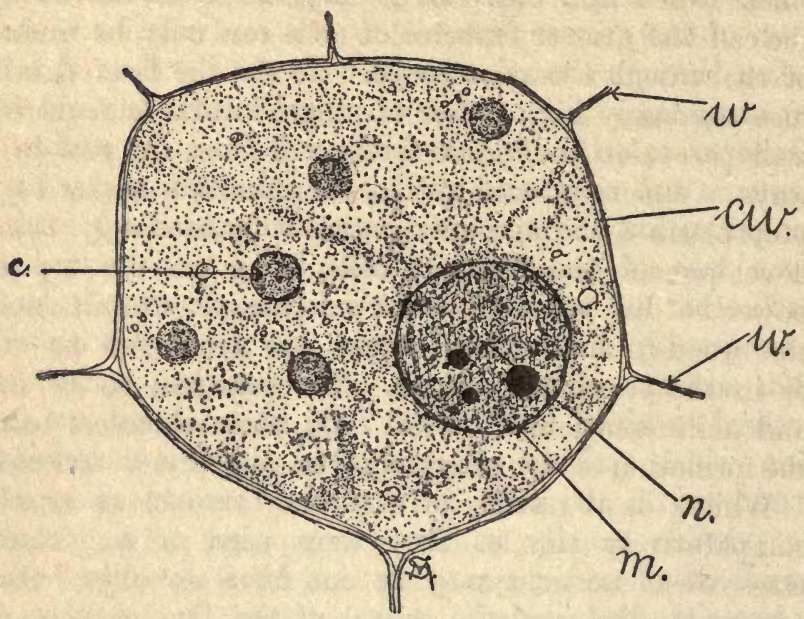

FIG. 4.-A single cell from typical vegetative tissue, $c w$, the cell wall, $w$, the walls of the adjacent cells, showing how they fit into each other to make a honeycomb-like mass. The cell is flled with granular protoplasm, in which lie $c$, the chromatophores, and $n$, the nucleus. A membrane, $m$, surrounds the nucleus, which is of denser composition than the protoplasm, and has several granular masses of a proteld nature in it.

granules which vary according to the nature of the cell. The commonest of these are starch grains, proteid granules, oil drops, and, in cells from the leaf or the outer part of a young stem, green chlorophyll granules. All these materials are not a fundamental part of the protoplasm, but are a result of its activities.

In the figure we see a sketch of a typical resting cell. Such is the mature and permanent condition of many 
cells. On the other hand, such a cell may continue to add to the material laid down in its cell-wall, and may do this to such an extent that the wall attains a great thickness and the cell may become what is called sclerised. Sometimes the cell elongates meanwhile, and a long, thick-walled fibre is formed. By the modifications of the cell-wall also, the much elongated and complex vessels of the vascular tissues are characterised. Several cells fuse together, end to end, for their formation, and the walls are thickened and sculptured in many different ways. When such modifications have taken place the protoplasm and nuclei of the cells die, and no further development is possible. The cells which retain the power to divide and form new tissue, whether it be in the wood-forming cambium, in the stem-growing tip, or in the sexual organs, such cells remain soft-walled and undifferentiated. In all such cases of division and the formation of new cells the prime mover is the nucleus.

While it is at rest the structure of the nucleus appears comparatively simple. It is composed of a granular mass with one or two large and more definite bodies within it, the nucleoli, and between it and the cell protoplasm is a fine wall, the nuclear membrane. But when the impulse to divide has stirred in it its structure changes, and the granular substance kaleidoscopically becomes a long thread coiled many times on itself. In the meantime the nucleoli disappear, then the thread breaks up into short segments of equal length termed chromosomes. By this time faint striations are seen radiating from two poles in the nucleus, and the little rodlike lengths of the original thread arrange themselves on the equator of the striations. They gradually split and move apart from one another, equal numbers going to each pole. When they have reached this a line of 
thickening appears along the equator of the thread-like striations, and these gradually fuse together and separate by a wall the two groups of bent rods that went to the
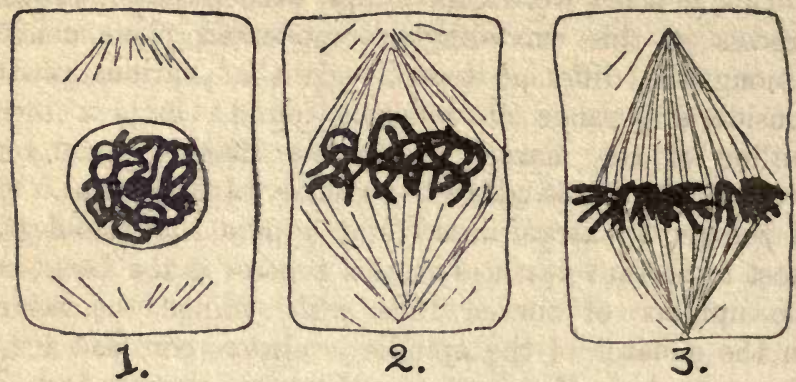

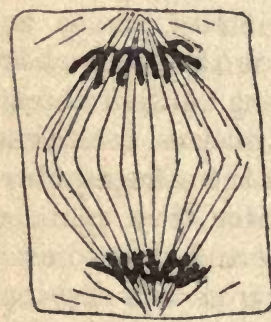

4.

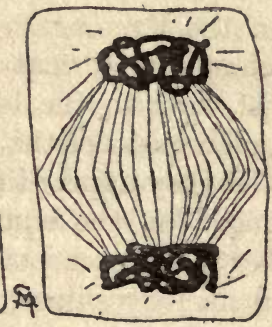

5.

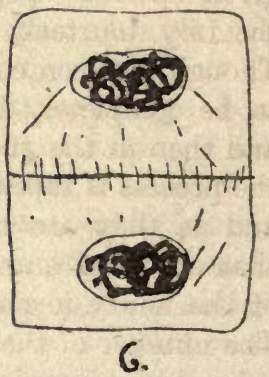

FIt. 5. - A series of simplifled diagrams to show some of the most important stages of the process (called mitosis) through which a nucleus passes in its division to form new cells. In 1 the chromosomes are in a tangled skein, in 4 they are separately seen as curved, horse-shoe like loops at each end of the nuclear spindle. 6 shows the two nuclel of the daughter cells settling down to the normal, and the wall nearly completed between the results of the division. In rapidly growing tissue (such as root tips) these cells will quickly grow to the size of 1 , and then go through the process again.

two poles. At the poles these rods intertwine and unite to form a long tangled thread once again, and this reverts to the condition it was in in the original nucleus, and we see a granular mass with nucleoli at each pole. 
The fine polar striations have disappeared, and their thickenings alone remain, and form the cell-wall, dividing the two newly formed cells from each other.

This, in a few words, is a simple account of the typical process in this exceedingly complicated phenomenon. Among the different tissue regions of various plants considerable range of detail is found. It is a mere outline of the marvellous process that is undergone every time a cell is added to the body of the plant. One of the most extraordinary and apparently one of the most important features in this process is the fact that the number of curved rods which range themselves on the equator of the spindle is always constant for a given species. For instance, there are twenty-four in the Lily, fourteen in the Evening Primrose, and so on. Though between each spindle formation the rods appear to be completely lost, first in the long tangled thread and then in the granular mass of the nucleus, each time the process is repeated they appear in the same number, and as they are ranged on the equator they split, so that an equal number go to each pole and thus to each of the newly formed nuclei resulting from the division. The number of these rods varies in different species, but it is seldom very large; in some parasitic animals it is as low as four. They are called technically chromosomes.

One of the not least remarkable features of this whole process is the fact that the stages described and illustrated above are found, not only universally in plants, but also in animals. In their ultimate structure plants and animals approximate closely, though in the kinds of tissues formed by the aggregates of their cells, and in their external features, they differ widely.

Mention was made in the previous chapter of the fusion which takes place between the male and female 
nuclei. This is the act of fertilisation when the two nuclei melt into one another and become as one, though the distinct chromosomes retain their individuality. The stimulus which results starts the active production of new cells by the repeated division of the original fertilised egg cell, and ultimately tissues differentiate. But as the number of those rods (chromosomes) in the dividing nucleus is fixed, it would appear that the introduction of the male nucleus should perpetually double the number, and thus disturb the regular specific character. This would take place were it not for what is called the reduction division, which occurs in both the sexes in the generation of cells immediately preceding the actual male and female nucleus. By this means there is but half the normal vegetative number in the two fusing cells, the egg cell and the male cell, and so when they fuse the number of chromosomes is doubled and thus brought back to the number normal in vegetative cells for the particular species.

There are innumerable interesting details connected with the reproductive cells, and indeed the work of cytologists is principally with such problems. The extreme delicacy of manipulation and the accuracy of observation which are required make the study preeminently one for specialists, and also account for the diversity of opinion which now prevails regarding many fundamental questions. As each new individual of a new generation arises from the divisions of the fused egg and male cell, it is certain that its characters, which are largely inherited, must have been transmitted in the minute structure of those two cells. The male cell is generally much smaller than the female, even though that is itself microscopic, and as the male enters the female it is said to lose all its outer protoplasm 
and enters the female nucleus simply as a naked nucleus. It is, therefore, supposed that in the nucleus alone all the inherited characters are carried. As the definite rods (the chromosomes) appear always to be so constant in the nucleus they have been suspected of being the actual bearers of the inherited qualities. There is, however, such a small number of them in comparison with the number of characters to be carried that they cannot be the ultimate units, and many theoretical, ultra-microscopic structures have been imagined to do the work. Finality has not yet been reached, though it lies within the province of cytology to discover the nature of the structures that carry the transmitted characters, and that are consequently of such exceptional interest to us, for in man the problem is ultimately the same as in the plants; and in the ultimate units composing the chromosomes, it would appear, lies the basis of our mental as well as physical characteristics. Some evidence goes to show that the cytoplasm is also the bearer of inheritable characters, but its importance in this respect has not yet been demonstrated so fully as that of the chromosomes. Plant cytology is of supreme importance in dealing with these questions, because the nature of plants makes them such suitable material for experiment. 


\section{CHAPTER V}

\section{PHYSIOLOGY}

THE life processes and reactions of a living entity form the special study of Physiology, whether it be of plants or animals. These life processes and reactions among plants are not nearly so obvious as they are in animals, but many of them are strikingly similar in the two classes of creatures. The most fundamental difference between plants and animals is in their methods of feeding. The plant is constructive, and works up for itself the simplest elements into food, while animals are ultimately destructive and, in using these same elements, destroy their combination, and leave them in a form which is useless for food until they are once more worked up by plants. All the carbohydrates, the starches, and sugars, and all the nitrogen compounds, the proteids, are ultimately provided for the whole animal world by the plant world. The study of nutrition, then, is one of the important branches of physiological work, but it is not by any means the only one. The breathing, drinking, and moving of plants must also be studied, and their appreciation of and reaction to light, heat, and gravitation. The sum total of all these reactions and responses results in what we call, simply, growth. And this "growth" is expressed by the stretching, enlargement, or alteration in shape of the organs and their increase in numbers according to certain rules and rhythms, which are also studied by 
the physiologist. Finally, the ultimate result of all the growth and reactions is the reproduction of the individual; and the details of this culmination are also within the province of physiology.

Though the physiologist looks on the plant from quite a different point of view from the anatomist, the morphologist, or the cytologist, he must, nevertheless, take into consideration the results of their work, for there is no use in trying to make observations on the work of a machine unless you know how it is put together, and what it is intended to do. The physiologist must also have a considerable knowledge of organic chemistry, for the processes that go on in the organs of plants in the course of their breathing, feeding, \&c., are in reality complex chemical reactions, the key to the comprehension of which is a knowledge of the simpler reactions which can be made to take place in testtubes and retorts. Indeed, a laboratory for the advanced study of plant physiology appears outwardly very much like a chemical laboratory, with its glass tubes and reagents and complicated pieces of apparatus.

Speaking as a physiologist, the leaf is the most important part of a plant. The leaf is the actual factory of the food of the world. In the leaf the carbon is extracted from the carbonic acid gas in the atmosphere, and is worked up with the hydrogen and oxygen in water to form soluble sugars, and is deposited temporarily in the leaf as starch grains, which are carried away as sugars and deposited ultimately in roots, stem, or other places of storage. The atmospheric carbon dioxide enters the leaf through the pores or stomata in its epidermis, and the water which is in every living cell is supplied from the soil by the roots. The process of turning these simple elements into the 
organic compound, starch, is called carbon assimilation, and it is only possible for it to take place in those parts of the plant where the cells are green, or rather, it only takes place in the cells which contain in their protoplasm small green bodies called chloroplasts. These chloroplasts, by reason of their colouring matter, are able to use and convert the energy of the sunshine to supply the chemical energy necessary to cause the combination of the elements that form the starch. In the darkness the leaves are like a factory in which the engines have been stopped and nothing can be done. It is only in the light, with a supply of the atmospheric gases and of water, and with the green bodies in a healthy condition, that the manufacture of food can go on. Some plants, or parts of plants, do not appear green, but are red or some other colour, as in the case of the red seaweeds for instance. This does not necessarily mean that they are not producing their food, for sometimes coloured sap or other granules mask the chlorophyll in the cells, but without interfering with their aotivities. On the other hand, some coloured plants, such as the brilliant toadstools, for example, are not able to make any food at all, for they are fundamentally devoid of the ohlorophyll grains. Such plants can only get their food by stealing it from some living green plant, or by using what is left in the protoplasm of dead ones. Such chlorophyll-less plants correspond to animals in their nutrition in that they have not the power to work up the simple elements for themselves.

Important in nutrition as are the carbohydrates, the manufacture of which we have just indicated, they are not alone enough for the nutrition of protoplasm, whether of plant or animal. Some nitrogen and a few mineral salts-among which iron, phosphorus, potassium, 
and sodium are very important-must be worked into the complex molecules which form the basis of life. These mineral salts the plant gets in weak solution from the water in the soil. Curiously enough, although all the solid carbon it requires it can obtain direct from the atmosphere, in which there is such a small percentage of gas containing it, the nitrogen necessary can only be utilised when it is in compounds in solution in water; and all the abundance of gaseous nitrogen in the air is useless to an ordinary plant. Hence of the manures that must be added to soil that is exhausted by the growth of many generations of plants upon it, those containing nitrogen are of great importance. A few plants are able, with the help of certain bacteria, to obtain nitrogen from the air, and these are to the farmer of the greatest assistance. Clover, Peas, Lupins, and indeed the whole family of Leguminacer, as well as a few trees, have on their roots small swellings which are produced in connection with, and inhabited by, bacteria. There are also in the soil other bacteria which do part of the business of turning the free nitrogen in the atmosphere which permeates the soil into chemical compounds, which are then further worked up by other bacteria till the clover and other plants with bacterial nodules are able to utilise the resulting mineral solutions. Simple experiments can be made to illustrate the need of plants for the solutions of nitrates, iron, \&c., by growing series of seedlings in glass jars, some in distilled water, which is devoid of any minerals, others in distilled water with all the necessary salts in solution, and others in solutions with one or more of the important salts missing. For instruction in this and the other experiments that can be made to prove the general facts of nutrition and assimilation stated above, 
reference should be made to a text-book of plant physiology.

The water, which is so important to the plant because it holds the necessary food-minerals in solution, is also essential in another way. The living protoplasm must not only be permeated by water, it mast have sufficient in it to keep the cells firm and taut. A plant immediately "droops" when the water contents of the cells is reduced, and instead of the stems being brisk and upright and the leaves spread out to the light, the stems and petioles fall and the leaves crumple up. So that, in addition to the food content of the water, the plants need the water itself, and may be as truly said to drink it as that we do so. Many of the organs and tissues of the plant have their part to play in keeping the water current going. By the chemical process of osmosis the soft-walled root hairs draw in the water from the soil; from these cells it passes from cell to cell of the root till it reaches the long, specialised wood vessels (which we noted as of so much anatomical interest), and up these it passes into the corresponding cells and ressels in the wood of the stem, thence, by similar cells in smaller bundles in the leaf stalks, it passes out to the expanded lamina of the leaf itself. There, in the cells of the leaf laboratory, it is chiefly of use, but as each single drop of water contains only a minute amount of nitrates, \&c., in solution, any given water drop is soon exhausted, and must then be replaced. Before it can be replaced, however, it must be got rid of, for the cells are each bounded by cell walls, and have, therefore, a limited capacity. The walls of these cells are delicate and permeable, and they are loosely packed in the tissue of the leaf, so that there are many air spaces between them, and this air is in 
continual circulation because it is in direct continuity with the general atmosphere through the pores in the epidermis. This air, circulating round the thin-walled cells, tends to dry them, and thus removes the water from them almost as fast as it reaches them through the other tissues from the roots. Hence a stream of water vapour is constantly being given off from the leaves. The circulation of water from the soil through the roots and stems and from the leaves once more into the atmosphere is technically called the transpiration current. When all goes well with a plant in this circulation of water the roots supply as fast as the leaves give off, and the cells are provided with all they want, but in a drought, when the soil is parched, or if the connection with the roots is severed, the leaves give off more than they are receiving, and the plant wilts and will ultimately die of lack of water. The amount of water that is kept in circulation by a large tree is enormous, as is brought home to one by the bleeding of a trunk that has been cut off in the spring, when the sap is flowing fast to supply the call of the young leaves.

One more relation to the atmosphere must not be forgotten, and that is the breathing of plants. It is a widespread error to imagine that plants do not breathe at all, or else to confuse the carbon assimilation with breathing. The process of breathing is really one for the oxidation of the tissues, and in both plants and animals oxygen is taken in for this purpose; some of it is used, and the waste product resulting is carbonic acid gas. In the lungs of animals this process goes on simply, but in the leaves of plants, where it also goes on, it is masked by the other process of feeding, in which carbonic acid gas is taken in as food and split up, and 
oxygen left as a waste product. Nevertheless, in every leaf the two processes are going on simultaneously in the same cells at the same time during the day. At night, when it is dark, the carbon assimilation ceases and the process of breathing is not masked, and, consequently, the only gas given off by the leaves is carbonis acid. It is this fact that has led to the old wives' tales that plants are healthy in daytime but poisonous at night.

Breathing, eating, and drinking are the most vital functions in a plant's life, for if any one of these gets seriously out of order the individual must die. Growth may be arrested, reproduction may be delayed, but in most plants breathing and feeding dare not be interrupted for long. In the cases of hibernating animals and hibernating plants, such as our trees when the leaves are off them, there is plenty of food stored in the tissue cells to carry on the passive life of a sleeping organism.

The plant's responses to the many other stimuli which it is capable of perceiving to a greater or less degree, are generally found to assist it in the main functions of its life. For instance, take the case of the plant's sensitiveness to light-heliotropism, as it is called by the professional physiologist. That stems and leaves grow out towards light the geraniums in any cottage window demonstrate. The simple mechanical explanation of this bending towards light is that the light actually tends to retard the growth of individual cells, thus those on the shady side of the leaf stalk grow more quickly, and the whole stalk is consequently curved towards the light, carrying the leaf blade with it. This growing towards light is an inherent character in these parts of plants. It cannot 
be said in any way that the plant knows that its leaves require the light, and yet the result in the plant's whole economy is that the tendency to grow towards the light places the leaves so that the necessary light falls on. them, and they are thus able to perform their function of food-making for the benefit of the whole individual.

Another influence which helps to direct growth is the attraction or repulsion of gravitation. The plant, in some way which has not yet been fully explained, is able to perceive whether it is growing in the direction of the force of gravitation or at an angle to it. The minute starch grains in the tips of organs fall to one side or the other of the cells as the position is changed, and it seems probable that they act somehow like the "statoliths" in the invertebrate animals. Not one organ alone, but various parts of the plant, react independently when the position of the whole is ohanged. This sensitiveness is called geotropism, and is the main cause of the roots growing down into the earth and of the stems growing upright in the air. Such plants as climb or creep are affected by other influences which to a greater or less extent counteract the rectangular response which is normal in most. An illustration of the strength of the effect of gravitation may be well seen in a tall herb which has been "laid" by the wind or broken under foot in an empty flower-bed. It will begin to "raise its head" in a few hours, and the end of the shoot will grow upright. That this return to the upright position is not due to heliotropism or the growth towards light is shown in the case of a plant in an empty flower-bed, for there the prostrate leaves would not be overshadowed by other vegetation. The fact that the different organs respond differently to gravitation, and roots are positively geotropic, 
while the stems are negatively geotropic, is of the greatest importance to an ordinary plant, for the function of the roots is to grow into the soil to hold the plant and to absorb water from the moist earth, while the function of the stems is to grow out into the air and carry the food-producing leaves into the light and air, where they get the essentials for their manufactures.

Another physical factor to which plants are sensitive is the temperature. Heat and cold have a great influence on the growth and activity of all the parts. Roots which are chilled cannot absorb water, and it will be remembered how essential that is for the wellbeing of the individual. On the whole, most vegetation responds favourably to a comfortable warmth. But the range of temperature is not very great, and excessive heat is bad for, and finally kills, most plants, except those strange little algæ which inhabit hot springs.

The fact that both cold and heat are bad and a nice medium warmth is the most favourable temperature for the general life, illustrates one of the interesting results of a scientific study of plant physiology. A similar, though not nearly so easily noticeable, series of processes is observed in relation to light. Darkness stops the food-forming activities of leaves (as well as affecting the tissues in other ways) and light encourages it. But this light must not be too strong or it is again harmful. True, in England, our plants do not generally get any opportunity of experiencing this, for the light intensity on these islands is not high; still experiments can be made with artificial light, and it is found that when the light becomes very intense it destroys instead of assisting the life functions. It is found, therefore, that there is a minimum quantity 
say, of heat or light that is endirable; that there is also a maximum quantity of light or heat beyond which the life suffers or dies; and that somewhere in between them is the best and most suitable quantity, which is called the optimum. This scale of maximum, optimum, and minimum quantities of light, heat, or whatever it is, differs for nearly every plant, and for the different organs in some cases. So that the most favourable, the optimum of heat for example, for one species may be too near the maximum of another to let it thrive at all where the first is most flourishing. The study of these "limiting factors," as they are called, is now one of the great branches of physiological work.

Each plant's relation to light, heat, air supply, water, and a number of the other physical factors in its environment can be expressed in series of mathematical curves or diagrams. 


\section{CHAPTER VI}

\section{EOOLOGY}

AFTER having outlined the departments of study in which the plant is considered individually-its relation to physical factors, its organs, and the cells which compose them-we must now turn to a wider field where the plant is merely an individual in a community, and consider its environment and its neighbours. This study of the plant in its home has been called ecology, from the Greek word for home. Just as sociology, as a branch of the study of human animals, is a comparatively new "subject," so ecology is a very recent branch of botany.

In a general way the communities which plants form have been recognised for long-we speak in common parlance of "woods" and "heaths," of "marshes" and of "moors"-but a detailed study of the relations of such groups of plants and their surroundings and of the laws that form such communities and hold them together was first started by Professor Warming, who is still living. The systematic study of ecology was, indeed, only taken up in England in the last ten years.

When we speak of "woodland plants" we bracket in our minds many individuals of very different types - not only the tall, woody trees, but the Bracken fern and Bramble bushes growing under them, and also the short-lived Blue Bells and Wood Anemones of the spring; and when we speak of the "moors" we think not only 
of the Heather and the Cotton Grass, but of the Sphagnum Moss as well. Such groups of quite dissimilar plants growing together form the communities, or "formations," as they are sometimes technically called, and, in a way, they correspond to a city among men where there is room for a certain number of tanners and bakers and printers and postmen, but where, if the community is to succeed, the types must not all be adapted to the same trade nor exactly the same environment. The interaction of the individuals on each other is as important a part of the environment as are the merely physical conditions. Indeed, among plants as well as among animals, they largely determine the physical conditions. For example, the ground immediately under a tall, spreading tree is often quite dry even in the heaviest rain ; it is then futile to measure the rain-s fall for the district and to assume that in that district all plants that require that rainfall would be happy in it. So in any community, because the plants are growing together, it does not at all follow that they require the same conditions for life; but that they fit into each others needs, and together help to adapt to their requirements the natural physical environment.

In speaking of a plant community or formation, however, one does not only consider the plants that form it, for to some extent we have, subconsciously in our minds, the thought of the physical nature of the locality in which the plants are growing. For instance, "a marsh" almost postulates the conception of a flat, low-lying, water-logged piece of ground, while "a heath " conveys the idea not only of a mixture of Heather and dry grasses but of a stretch of comparatively high land of a dry and often sandy nature.

If we take such communities as units and imagine a 
map of England or of the world in which the different areas covered by heath, moorland, woodland, marsh, and so on were coloured in different colours, then we can recognise at once that though the extent of the different patches would not entirely coincide with the different physical characters of the ground, yet there would be a distinct tendency for them to coincide, except where cultivation has seriously interfered.

Rich, warm soil, with a sufficiency of water which is well drainod off, yields most of the "normal" plants, while difficulties of any kind, such as the want of water on a high sandy soil, or the extreme scarcity of water combined with a troublesome shifty soil in the sanddunes, tend to produce plants with organs specialised to meet the peouliarity of the environment. Such specialised plants are among the most interesting and curious, for one organ is often elaborately developed, apparently out of all proportion to the others, as in the case of the little tufted plants, where there may be a root many foet long to provide a visible plant only an inch high above ground.

As a general rule, the strange modifications and elaborate devices in plant organs have taken place in relation to the water supply. Hence the study of those which live under desert and other drought conditions has been one of the most attractive and obvious fields of ecological work. The Cactus, with its leaves all turned into spines, and the fleshy-leaved Stonecrop, the plant with dry, rolled-up leaves or those thickly covered with woolly hairs, each finds these peculiarities an aid to retaining the scanty water which would not suffice to supply ordinary broad soft leaves, from which water evaporates rapidly. The Cactus and the leaves of the fleshy-leaved Stonecrop, by becoming cylindrical 
or spherical, much reduce the area of surface which can evaporate in proportion to their contents ; the rolledup leaves not only save the exposure of both surfaces at once, but, in general, their pores are only on the side which is rolled inmost, and so evaporation, or transpiration, takes place into the nearly closed cavity made by the rolled leaf instead of into the open air; while the woolly covering of hairs prevents the air currents sweeping over an unprotected surface and tending to dry it, for the felt of hairs helps to keep the air stagnant over the pores and thus to reduce the amount of transpiration. Reference must be made to the numerous instances of such adaptations described in nearly every book on botany.

An interesting point to notice is the tendency that several swamp and salt marsh plants show to develop some of the characteristics of desert vegetation. This is to be explained by the fact that the water, which is present in abundance in a physical sense in swamps or salt marshes, is wanting in a physiological sense, because water that is heavily charged with humic acid or with mineral salts is of very little use to the plant. As we mentioned in the chapter on physiology the roots absorb the water in the soil by a process of osmosis. Now, in this chemical process the majority of the compounds dissolved in the water enter with it, but if the solution is too strong then more salts enter in solution than the cells can use up, and the cells get clogged and poisoned. Hence the entry of the water must be restricted, and hence the surface transpiration must not be too great, and the plant is as badly off for water as if it were living in a region where there is very little in the soil.

In considering plant communities we have not only 
a host of such facts to notice, but also the relation of the various kinds of plants to each other. For instance, many of our typical spring woodland flowers only grow in the woodland community because at the time when they are most in need of light the tall trees above them have not yet got their leaves, and the light comes sufficiently between the bare branches. In the eternal shade of a wood composed of evergreens we do not find the same carpet of flowers as in the light, deciduous forests.

One other illustration of this must suffice-the Creeping Willow and many other plants of the sand-dune would never have been able to grow on the shifting sand at all if it had not been for the sand-binding grass, the Psamma, which forges ahead into the bare places, and makes a substratum firm enough for the other plants to inhabit.

It will be realised, consequently, that the various species are not only adapted to different features in the environment, but that the peculiarities of one species often prove to be most useful to another by preparing and changing the physical features of available soil. The morphologist and the anatomist look on the peculiarities of the individual as adaptations for its own purposes, but the ecologist takes a broader view than that and sees the various types interacting and interdependent.

Further even than this the ecologist must go and see the plants actually affecting the physiography and even the geography of some districts. A good illustration of this is seen in that very sand-grass just mentioned. The loose sand thrown up by the sea is blown by the wind to and fro and piled up in mounds only to be scattered again as the wind changes, but once the creep- 
ing rhizomes of the sand-grass get a hold on it their power is greater than that of the wind, and by means of the long ramifying roots and the branching rhizomes the sand is held together long enough for other plants to come in and to establish themselves one by one till the surface of the sand is covered. In this way acres of dry land may be accumulated, and its character changed from that of the bare sand of the shore to the dry pasture land of the low heaths.

The series of different kinds of plants playing "follow my leader" into the fresh water ponds is another good illustration of the power of the unaided plants to change the nature of a given spot. Into the open water of a mere or pond, with its minute flora of microscopic alga, push out the underground rhizomes of the Phragmites reed and the Bulrushes. They send up tall shafts with leaves and flowers, and in the autumn these die down, and the half rotting and fibrous remains are tangled together with the roots and rhizomes, and all tends to catch any further fragments or detritus that is drifting in the water. Gradually, by this means, the reeds collect a soil which tends to make the edge of the pond shallower, so that the Bog-Bean and other shallow water plants can come in and help in the work till so much soil is accumulated that the water is quite shallow, and rushes and Queen of the Meadow and King Cups grow on little marshy mounds with water all round them. These close up, and grasses and sedges and Buttercups grow in between, and the land is almost firm and established enough to be called meadowland. Behind the grassy strip creeps down the forest, and the trees, keeping their distance behind the zone of grass, advance with its advancing edge till in time the opposite shores meet and the forest closes over the space once occupied 
by the pond. When this has happened we see that the one community of plants, viz., the woodland, has ousted the other, the community of water plants. It is not only individuals that struggle against each other, but whole communities that usurp each other's place. Here, indeed, we can hardly say that there is a struggle between the land and the water plants and those of the shallow shore, because by their natural growth and accumulation the former merely follow on where the latter have, by their own growth, rendered the place no longer suitable for themselves, but well adapted for those which need a built-up soil.

Recently it has been recognised that there are definite laws which govern the series of communities that inhabit a region, and a trained ecologist, seeing one set of plants growing under certain conditions, can predict accurately what type of community will follow italways supposing that there is no great physical change, such as would be caused by the sweeping away of the land by a great flood or its disturbance by a lardslide.

When such a case as this occurs, and we have bare fresh land exposed, it is of interest to watch the way it is colonised. The general law that is followed is a series of changes, first from an entirely bare space to one with a few species scattered at fairly regular wide intervals over the surface, then by more species, the individuals growing closer together, but each still with space to develop completely. At this stage there are generally a very considerable number of species in proportion to the actual number of individuals. Then the species really adapted to the soil and the conditions begin to take a firm hold, and they grow more crowded together and oust the others, till at the end, when the vegetation for the spot is firmly established, there are 
great numbers of individuals which completely cover the ground, but there are comparatively few species.

In every case the plants of a spot depend to an enormous extent on the soil. Many species are exceedingly sensitive to very small traces of such compounds as lime, silicates, salt, \&c. Some can only live when supplied with lime or chalk, which to others is wellnigh a poison. It is well known that the Orchids and other plants which grow on the chalk downs cannot live on the quartz sand of an old dune.

In a country so much cultivated as England, however, it is often difficult to see the direct influence of the soil on the communities of plants growing on it, for hardly any of the fields which form so great a part of the land have not been subjected many times to manuring and planting and to the weeding out of the original inhabitants, either entirely or in part.

The seashores, with their salt-marshes and sanddunes, and the freshwater ponds, where the land plants are encroaching, are, perhaps, the best illustrations of natural communities which are available for ecological study in these islands. 


\section{CHAPTER VII}

\section{PALAEONTOLOGY}

WE have merely hinted at an outline of the branches of study in the modern plants, but that outline suggests the great extent of detail that must be offered to the student by the thousands of living plants that have already been named. The palæobotanist is faced by a still vaster problem, for in the last thirty million years or so, during which the world has been a comfortably habitable place, the races of plants have never remained the same, for each is altering, evolving, or "devolving " (if the word may be used in a new sense) all the time. Even at the present time it must be actually true, though we so seldom observe its slow progress, that no species is fixed and stationary for long together. Everything is either evolving or dying out. A student of fossil botany, therefore, has not only to consider all the plants of any one given epoch, as has the modern botanist, but he is concerned with series of vegetations which differ more or less from each other according to the length of time that separates them from each other.

Of these it is probably not a wildly extravagant estimate to say that twenty-nine thirtieths are extinct species. If they are extinct, that means that they are no longer alive-how then can they be studied?

If you walk along a shore to-day at high tide you will find many fragments of land plants in the débris, not only orange peel and banana skins brought by man, 
but leaves and branches and bits of wood brought down by the rivers and drifted out to sea. Often a slight change of current or a higher tide will cover these scraps with sand or silt, and if they are well covered they are perserved from decay between the layers of fine silt or mud. This is one of the ways fossils are formed. There have been seashores with sand and mud washed up by the waves ever since there have been habitable lands, and from all the epochs of early time, with all their different kinds of plants, there have been fragments here and there preserved on the old seashores or in the deposits that once formed the bottoms of lakes or broad rivers. Buried with the mud or sand of these shores and lake bottoms, deposited now here and now there as the physical geography changed, are remnants of the vegetation that was living in the various epochs. Sometimes the local currents favoured the deposition of many plants in one place, and at others there are almost no remains of the local vegetation. From the fragments in the rocks palæbotany pieces together the ancient plants, and in some fortunate cases can discover, not only what they looked like externally, but also the very details of their internal anatomy.

The aim of palæobotany is to restore the whole series of plants that have lived upon the earth. If that were done completely then there would be no need for the further theorising about past evolution; we should have before us clear evidence of the actual series of forms through which our recent plants have evolved. But this state of affairs is excessively remote, for at present we have only rescued from the preserving strata of the rocks fragments of the extinct genera.

These fragments, all of which are called fossils, are 
preserved in three main ways. The first and best known are impressions. These we see when we split open a slab of shale or limestone, and a fragment of a fern leaf, or a branch with its foliage, lies pressed between the layers of the rock. Sometimes these impressions look quite black against the stone, and this is due to the carbonisation of the regetable matter of the tissues. In such an impression we have the external form of the plant retained as if it were a pressed specimen, but all its internal cells are decomposed.

The second form of fossil is the cast. Here, as in the previous kind, it is generally the external features of the plant that are preserved. The cast is formed by the enclosure of the parts in some generally finegrained, detrital matter. This retains the plant until its characters are imprinted on it, so that when the vegetable tissue decays the rock still holds its features, as plaster of Paris holds the engraving of a medal. Both casts and moulds of plants are formed, and sometimes, too, we find casts of the internal features of hollow stems.

The third and most useful form of fossil is the true petrifaction. In this case there is often no sign of the external features of the preserved plant. A mass of silica, or of carbonate of lime, or of dolomite, entirely encloses, permeates, and petrifies the inner tissue cells and the wood of stems or leaves or seeds. Thin sections of these stony masses can be cut in the same way as sections are cut of minerals or fossil corals. Then, through the microscope, we can see the cells just as they can be studied in sections of living plants. From series of such sections we can restore not only the internal anatomy of plants that have been extinct, perhaps, for millions of years, but even points in their cytology are discoverable. Such fossils can sometimes 
be associated with impressions which show the external form of the plant till we have a fair idea what it was like both inside and out. From these data we can do something to deduce the ecological condition under which it grew. This again leads us on to consider such data as indicators of the climates of the departed continents. Hence we see that the field that is opened up by fossil botany is a very extensive one.

This branch of the science is, indeed, only in its infancy, but it has obtained some results of great interest. One or two of them we should now consider.

Without recapitulating the elements of geology, it is well, perhaps, to point out that the epochs of the world's history, since the deposition of the sedimentary rocks began, have been found to be characterised by different series of dominant animals-first, the lower invertebrates, then the simple vertebrates, such as fishes, then the higher in the scale, up to the mammals, and, lastly, in very recent times (speaking geologically) man himself. The history of the plant world seems to be expressed in a similar series, and, on the whole, there is a wonderful agreement in result between the study of the plant and animal fossils.

If we begin our study of the botany of the past at the end nearest the present, then the first really important point to notice is that in comparatively recent times in England, in the middle and lower Tertiary rocks, for instance, there must have been a rather different climate from the present, for we find remains of Palms and other semi-tropical plants in these isles.

We do not have to go very far back in the history of the whole earth to come to the time when none of the higher plants were living at all. All the members of the huge and important group of Angiosperms are of 
comparatively recent origin, for not one really undoubted specimen of this now dominant family has been found in rocks older than the base of Cretaceous times. One or two very rare and doubtful fossils, which may be Angiosperms, are known as far back as the Lias. We have then to picture in all the earlier epochs a vegetation in which not only all the living species are absent, but one in which the leading families now dominating nearly every locality in the present earth were not at all represented. There were not only no trees of the nature of Oaks, Beeches, or Poplars, no Daisies, or Lilies, or Roses, no Palms, but not even grass. In the times preceding the earliest Cretaceous, when the advent of these modern families changed the face of the vegetation, the most highly evolved family appears to have been one which is now extinct, but was not unlike in external appearance the rare family of Cycads still living. In several ways these curious plants may be taken as a parallel in the vegetable kingdom of the strange Duck-billed Platypus in the animal world.

While the extinct members of this cycad-like group took the highest place in the scale of evolution of the then existing plants, several members of the lower families were abundant and bore a more familiar aspect. Pinetrees, very similar to those now living, must have been numerous then, as well as members more or less closely allied to the present Monkey-puzzle (Araucaria). There were also numerous ferns which differed externally but little from many living genera, and there must have been club-mosses, though we know but little about them at that epoch. There were also large and small equisetums, very similar in habit to those now living.

Going back to the earlier times, the plants get increasingly unlike the modern types until we get back to the 
true Palæozoic epoch. From the point of view of the fossil botanist this epoch is unique because it includes the period of the Coal Measures. During this period in Europe there was not only a remarkable tendency to produce coal in a number of successive layers, but the plants which provided the necessary vegetable matter for the coal layers were fortunately preserved in large numbers. All the different varieties of fossils-casts, impressions, and very wonderful petrifactions are abundant in deposits of this age. We have, consequently, a more complete knowledge of the flora of the Coal Measures than we have of any other epoch, excepting that of the present day. All the genera and species from these beds are not only extinct but are fundamentally different from forms now living. Many great volumes have been written on the plants of the Coal Measures, but we must only glance at one or two of the more interesting of them. Those highest in the scale were probably the fossils well known as Cordaites. They were tall trees with solid woody shafts and long, sword-like leaves, and they bore seeds in cones which were more complex than those of the living family which is least remote from them, the Monkey-puzzles. But the majority of the large tree-like forms of these times were much more remote from any living trees than were the Cordaites. The two genera, Calamites and Lepidodendron, were large trees with very numerous different species. Their shafts were sometimes as much as three or four feet in diameter, and many specimens have been recorded that show that they reached the height of tall forest trees. The bulk of the stem was composed of softer tissue than is usual now in any self-supporting tree, but there was a quantity of the regularly developed secondary wood which is now only 
found in plants of the Gymnosperm and higher families. The early treas, however, belonged to a much lowlier family, to the Lycopodiacex, which ranks below the ferns and is now represented by the Club-moss or Lycopodium, and the delicate moss-like Selaginella, which is so often cultivated in greenhouses. It is improbable that any living form is actually descended from these giant treo forms of the coal forests, though sometimes the modern genera are spoken of as the degenerate representatives of the old stock. A truer statement of the case would be that the family, as a whole, reached its acme of success in these early times, and that the dominant position in the forests having been won from them by the higher plants as these evolved, the only representatives of the group for which there remained room in the scheme of things are the small green herbs. Using the words in the accepted sense, which implies advance, it is impossible to say that the modern lycopods are more evolved than the fossil ones. Both in the structure of their wood and in their complexity of fructifications, as well as in their large size, the fossil trees represent more highly organised organisms than do the simple modern herbs. One remarkable genus of the fossils (Lepidocarpon) had large fructifications whioh almost amounted to seeds, while to-day the true lycopods have only simple spores. It appears that not only do individuals have a lifetime of waxing and waning, but so do families as a whole, for it is certainly true that in the time of the Coal Measures one of the most numerous, successful, and dominant types was the Lycopod family, which now is represented by few and small species.

A history almost parallel to this belongs to the other great pteridophytio tree group of the Coal Measures- 


\section{PALAEONTOLOGY}

the Calamites. Their modern representatives are the Equisetums or Mares' tails, which are often very numerous in the places where they grow at all, and which are represented by species adapted to life in dry ground and others that inhabit shallow water. The English species do not exceed a few feet in height, but there are some foreign ones that grow in groves together and thus help to support each other's slender shafts to a height of twenty or more feet. These plants must represent on a somewhat smaller scale much of the external appearance that was probably presented by their sturdier and more complex ancestors.

One other family from the coal flora must be mentioned-and this is one that has now no relative still living. Its existence would never have been suspected had we not had detailed knowledge of the fossils. This group was recently discovered, or rather recognised, and named by Professor Oliver and Dr. Scott-the Pteridospermæ. Its name indicates the nature of the group, for it means Pteridophytes, that is fern-like plants bearing seeds. Among modern plants seeds are only borne by the higher families-the Gymnosperms and the Angiosperms, ferns and all the tribes below them having nothing more advanced than spores. Hence this ancient group which connects the fern-like plants with those which bear seeds is a most important link in the chain of evolution of the regetable world. There are many side issues of interest connested with the recent discoveries of these fossil forms, and one of these is the stress it has laid anew on the dictum which all know and all ignore, viz., that appearances are deceitful. One of the most generally accepted tenets about the flora of the past in Coal Measure times had been that it was the "Age of Ferns," because there 
were such large number of fern leaves among the fossils representing the epoch. The impressions of these fern leaves were sometimes remarkably perfect, and showed the form of the divided fronds which in externals so much resemble modern forms. The first clue to the discovery that these plants were not what they seemed resulted from the study of the specimens which have their internal cells petrified. Under microscopic examination their internal anatomy was found to be much more highly organised than that of modern ferns. The discovery from petrified remains that these plants bore seeds of complex structure was followed by the recognition in impressions that several other species supposed to be ferns also had seeds attached to their fern-like leaves. There are now grounds for supposing that a large proportion of the "ferns" of the Coal Measures belonged to the higher seed-bearing group of the Pteridosperms. This extinct group bridges one of the great gaps in the series of modern plants. Among those which are still living to-day there are almost none which indicate the connection between ferns and seed-bearing plants. Clear-minded botanists some time ago had seen some obscure points of structure that hinted to them that some such connection must at one time have existed, but the exact form which it took, and the time of its existence, were matters purely of the imagination. The Pteridosperms and all that they reveal are matters of fact.

It must not be supposed that these are the only trophies of the study of modern palæobotany. Every fossil plant that is discovered helps to fill in the blank spaces in the great genealogical tree, and many of them show quite as interesting or unexpected features as do the fossils just described. 


\section{PALEONTOLOGY}

When we turn to the rocks that represent still older periods of the earth's history we do not find nearly as much as we should like in the way of fossils. That there must have been plants, and land plants too, in Cambrian and Silurian times, and probably earlier, is generally agreed, but their nature has not yet been revealed. That the Palæozoic forests with their highly complex Gymnosperms and great variety of vascular plants are very far from primitive is obvious. Alas, that the plants recorded from the earliest times should as yet reveal very little indeed about the origin of things.

It is indeed doubtful whether human knowledge will ever get down to the roots of life. In the meantime, for our reconstruction of the ramifications of the branches of the tree of vegetable life, there is no source of facts to be compared to the fossils. 


\section{CHAPTER VIII}

\section{PLANT BREEDING}

Satisfactorily to define a species is one of the most difficult questions in botany, yet if one leaves aside for the moment the more abstruse considerations, it is possible for the present to get a tolerable idea of what we mean by a species. For instance, if we talk of "Blackberries," we do not indicate a narrowly defined species, for there are so many varieties of Rubus that some consider that there are really a number of species more or less closely related passing under the same name, while others look on the forms as all one species in a scientific sense, which has a number of sub-species or varieties. But if, on the other hand, we speak of the common little Daisy of our lawns we are more nearly indicating a true scientific species, for there is much less variability in its forms, and there is not such a plexus from which to disentangle our ideas of what a species is.

Even when we take a comparatively well-marked species, like the Daisy or the red Field Poppy, which cannot be mistaken for any other species, we find on comparing several individuals that there are slight differences in the shape of the leaves or in the hairs on the stems, or in the brilliance of colour in the petals. When plants which have arisen from a pure line of ancestry show such differences, it is considered that they are purely individual and that they depend on trifling differences in the plant's environment. On 


\section{PLANT BREEDING}

the other hand, plants which show a great amount of variation between the individuals growing together, are generally suspected of being the results of crossbreeding, or hybrids, as they are called, because by experiment it has been shown that the results of crossbreeding from slightly different stocks is to induce a great amount of variability in the offspring.

Now, in the vegetation which is untouched by manindeed in the past vegetation that had been flourishing before ever man appeared-there have been innumerable opportunities for cross-breeding, both between closely allied species and those remote in characters, because most flowers are open to the face of heaven, and there are the wind and innumerable insects to act as distributing agents for the pollen. Many flowers are so wonderfully adapted that the chance of unexpected pollen reaching the stigmas is very slight, while in all cases the mixture of two very remote races is prevented by the inability of pollen to develop in alien tissue. Yet that still leaves enormous possibilities for the formation of natural hybrids. A pretty example of natural hybrids with a good deal of variation is the case of Primroses and Cowslips, with the varieties of the hybrid Oxlips which have resulted from their interbreeding.

Scientists have not yet decided how much the variability in what appear as pure races is due to the immediate environment of the individual, and how much is the effect of interbreeding in the distant past of the stock, but, be that as it may, the fact remains that there is this variability, and that it is in the highest degree important to the farmer and fruit grower. Fruit or flower growers, for instance, cross the pollen from one plant on to the stigma of another that has some quality they want to breed. From the great variety of offspring in a successful cross they select the ones that approxi- 
mate most closely to the type they desire. After many generations of such breeding, forms have been obtained which differ materially from either of the original parents. The most notable gardener at the present time who has undertaken this work on a large scale and has obtained many useful or beautiful varieties, is Luther Burbank, who has extensive experimental gardens in California, and whose varieties of fruit are grown all over the world.

But though it is the most practically useful branch of the subject, the mere production of economic varieties is by no means the most interesting branch of the study of breeding in plants. The gardeners' results, as a rule, have been obtained by more or less haphazard crossing, and from them alone there are few indications of the great laws that underlie the production of the new forms and their bearing on evolution and heredity.

The great work of Charles Darwin, who established the theories of evolution and the flux of species on innumerable minute observations, is so universally recognised, and has had so many more or less popular exponents, that there is no need to enlarge on "Darwinism " in these pages.

All the problems of heredity and the means of transmission of characters are of supreme importance to the evolution theory, and, since Darwin, the next most important contribution to the knowledge of heredity was made by the Austrian monk, Mendel. He found that an extremely simple numerical law governed the appearance of the different characters in the second generation of the results of cross-breeding, and that, if we note any one given pair of characters, they appear in the second generation in the proportion of one of one kind, one of the other, and two of the mixed character. This can be expressed in algebraic 


\section{PLANT BREEDING}

form as follows:-where $A$ is one of the characters and $B$ the other the result in the second generation of the offspring is that, however many there are, they are in the proportion, $1 \mathrm{~A}+2 \mathrm{AB}+1 \mathrm{~B}$.

But this is not at once apparent to the uninitiated, for in the pairs of characters we find that one is stronger than the other and masks it. For instance, if one pair of characters is the smoothness and the hairiness of the leaf, then if the hairiness is the strongest character, the dominant, as it is technically called, it hides the other, and of the offspring we get one smooth, one hairy, and two smooth-hairy, which appear hairy, thus giving as an apparent result one smooth and three hairy. The existence of the smoothness in the hairy ones comes out when they are bred again, and from the two mixed parents, which looked hairy, one offspring js smooth, one hairy, and again two mixed.

Of course in any given individual there are the results of an enormous number of pairs of characters, and the more highly organised the organism the greater the complexity of the characters, so that the extreme arithmetical simplicity of Mendel's law is all the more surprising, and it stands out like a solid rock in a sea of uncertainty.

Nevertheless, the meaning of Mendel's work and the value it has, both for theoretical and practical purposes, was very long in receiving recognition. Mendel himself died (in 1884) before scientists had awakened to the realisation of his discoveries, and it is indeed only in the last cecade that there has been any considerable recognition accorded him.

Like all really great theories or formulated laws, that of Mendel has stimulated other workers to experiment, some with the object of proving and others disproving it, and the advantage of this is that innumerable new 
facts are in the meantime accumulated which might never have been sought for otherwise. Sometimes the results of the experiments have seemed at first very startling and difficult to explain. For instance, in the course of Mendelian work, one experimenter had two races of Stocks, one with white flowers and one with cream flowers. These were crossed in the usual way, and all outside pollen carefully kept from them. The resulting offspring were not white, nor cream, but a brilliant reddish-purple. At first sight this would look as if something was wrong with the laws the experiment set out to test, but in reality it indicated the interplay of other pairs of characters which affected the ones that were for the moment under investigation. Work such as this leads on through an endless chain of experiment, hypothesis, theory, and again, and all the way along, experiment.

Experimental work on these lines is, of course, done also by zoologists, but for many of the problems plants afford more convenient working material. Care at the time of pollination and in the collecting of seeds are the main things in plant breeding. There are few of the complicated pieces of apparatus required for such work as are necessary for experimental physiology, and, consequently, for a botanist cut off from the big institutions experimental breeding offers one of the most profitable fields of research. In modern experiments often thousands of specimens are grown all of one kind, and their pedigrees are kept for generation after generation.

Modern research in experimental breeding of plants received an enormous stimulus and a new direction from the work of Hugo de Vries, whose book on "The Mutation Theory" appeared so recently as 1901. The essential difference between the work and theories of 
de Vries and the modern school of experimenters, stimulated by him either to support or controvert his views and the original Darwinian conceptions, is the introduction of the conception of the mutant. The mutant is a new variety or species which arises suddenly and not from a gradual series of inherited modifications, and which breeds true. The best known example of a species which has given rise to such mutations is the Evening Primrose (Oenothera). Of the various species of this plant literally tens of thousands of carefully selected specimens have been bred by botanists all over the world, and the several old established species have yielded nearly a dozen of new, suddenly produced forms, all of which ultimately "breed true," that is, have offspring which, coming from seed, entirely resemble the parents.

The mutants of the Evening Primrose are not startlingly different from their original stock, but they are constantly and recognisably different. Their production at all is of great importance to the theories of evolution, for since their recognition it has been possible definitely to experiment and test this theory and the many others which arise out it.

At present the majority of plant breeders and mutationists deal only with external characters, but a few workers have begun to correlate these external changes with the minute details of the cytology. It will be remembered that in the chapter on cytology the importance of the nucleus was emphasised, and we know that all the characters that a plant inherits, whatever they are, must have lain in one stage in one of the two fusing gametes. A great field of experimental and theoretic work lies in the future in the correlation of the internal and external features in hybrids and in the so-called mutants. 


\section{CHAPTER IX}

\section{PATHOLOGY}

EvERY living organism is liable to have the balance of its delicate mechanism disturbed by some cause or another, and plants, no less than animals, suffer from a variety of such causes which destroy utterly, or merely locally affect their lives. The diseases of plants have not yet been studied so elaborately as those of animals, and "doctors" generally confine their attention to the higher vertebrates, but, nevertheless, there is a great mass of facts which have been accumulated about the various parasites and diseases which attack the vegetable world.

Accidents, like broken limbs or wounds caused by stones or sharp instruments, happen to plants as they do to animals. In such a case, if the individual to whom the accident happens is normally healthy, the tissues respond and attempt to heal the gap or to mend the fracture. In the case of trees such wounds arise oftenest by the felling of a trunk or by the snapping of a branch in a gale. The broken surface exposes inner tissues to the atmosphere, laden, even in the woods, with germs and microbes of disease, and the first essential is that the broken surface shall be covered. The plant makes an effort to do this by the growth of "callus." In the neighbourhood of the wound the cells are stimulated to divide and grow rapidly, and they attempt to form a healing tissue across the surface of the wound. 
Also of the nature of an accident are the various forms of poisoning that may happen to healthy plants. They may be poisoned by gases in the atmosphere, or they may be poisoned by minerals in the soil. In the cases of slow poisoning the growth of the tissues may be arrested or altered and truly pathological conditions set in, in which abnormal cell growths take place. On the other hand, where the poison is stronger, the plants simply die, as, for instance, when the paths are sprinkled with weed-destroying compounds. These enter the roots in the osmotic process of root absorption, and travel through the cells of the tissues.

Accidents may happen to the healthiest individuals; the pathologist is more concerned with the diseased ones and with those where the tissues are abnormal. One of the most fatal diseases that can overtake a plant is Chlorosis, or the lack of colouring matter. This disease, in its essentials, is very similar to anæmia in human beings, and as the plants depend on their colouring matter for the manufacture of their own food, an extreme case cannot survive at all. Chlorosis is an obscure disease, but in some cases it certainly appears to be caused by a lack of iron, and without iron the human blood is not red nor plant granules green. Generally the seedlings attacked by the disease die out very early, but sometimes sickly whitish-leaved specimens struggle along for a little while. The disease is often local, and in compound leaves one leaflet here and there may be entirely colourless. This character is best seen in the gardeners' "variegated" varieties, where the leaves are mottled or striped with cream-coloured patches and bands. The green parts there do enough work to carry on the life of the individual, while the colourless parts are non-producers. If this is not carried too far 
the plants can be quite healthy, but if gardeners tried to breed an entirely white race, it would die of malnutrition.

All the innumerable questions of nutrition come very near the borders of the study of pathology, for an illnourished individual, even if it lives, is much more liable to disease than a healthy one.

The great sources of infected disease for the plant world, as for the animal, are the fungi and bacteria. The higher plants are attacked by innumerable small parasitic forms of fungi, some of which finally kill the host. The study of the fungal diseases of plants is an enormous one, for there are thousands of species of infecting fungi, and in some cases they have most complex life histories and pass through cycles of two or three generations which inhabit different hosts. In the study of human and animal disease many instances are well known now of the parasite inhabiting several hosts, for instance, man in one generation and the pig or the mosquito in another. So it is with plants, and the disease which. works havoc with the grain crops goes into a new generation that inhabits the Barberry. Often the work of connecting the different generations of the same disease is rendered excessively difficult by the elusive and unexpected nature of the cycles; and it is only by the most careful breeding of the fungus producing the disease and by experiment that the actual data can be separated and the life history of the disease established. We are, once more, back in the highly equipped laboratory and studying details under the microscope.

The economic importance of plant pathology is selfevident, for the crops we eat are often attacked by disease, much of which modern science has learned to 
subdue. Still epidemics arise, and "rust," "smut," and "scab" are still known to the farmers. Potato rot and peach curl, spoiled fruit and wasted turnips are due to parasitic fungi. The pathological effect on the host plant varies with the kind of disease. In some cases its life is drained away with almost no outward sign, in others the presence of the fungus acts as an irritant, and abnormal swellings or discoloured lumps are produced by the stimulated tissue cells. These correspond to some extent to the tumours and swellings that occur in the tissues of animals.

Such swellings are also produced by animals in the plant tissue. These are often harmless enough, and merely locally disfigure the leaf or branch without materially affecting the whole individual. Such are most "galls" which are formed by insects depositing their eggs in the plant tissue, whose larvæ develop there and with their growth stimulate an abnormal development of the plant cells. These pathological tissues are often extremely interesting, and are developed with characteristic regularity according to the insect stimulating them. Zones of woody and fibrous coloured cells are developed pathologically in the soft tissues of leaves for instance, which would normally be incapable of forming any such cells.

A third type of attacking organism with which the ordinary plant has to contend is the higher parasite of which the Dodder (Cuscuta) is a well-known illustration. This pest belongs to one of the highest orders of the flowering plants, but by reason of its parasitism it has degenerated to a mere colourless thread which sucks all its nourishment from its host. It does its own flowering, however, and produces seeds which shortly after their germination begin their course of aggression. 
This parasite specially attacks clover, but heather, gorse, and other hard forms are not exempted from it. And while it does not produce pathological growths in its host, it simply sucks out its nourishment until it is destroyed and great patches of the host plant are killed.

Hardly to be considered actual disease, there are still other abnormal phases of growth of which mention should be made here, and they are the growing together of series of stems, or several leaves and stems or other parts to form a broad irregular structure. This is called "fasciation," and the tendency to produce it seems to be inherited. The hypertrophy of some organs and numerous other irregular departures of growth may affect plants as well as animals. Many of these are of special interest to the morphologist, for these "sports" have sometimes given the clue to the explanations desired regarding the interpretation of normal structures.

In every phase of this work, as in all other branches of modern science, large numbers of data have to be collected, tabulated, and correlated, and the resulting deductions tested by experiment. When the importance of agriculture and forestry are fully recognised, we may expect to see plant doctors and health inspectors augmenting the comparatively small number who today concern themselves with plant diseases. 


\section{CHAPTER $\mathrm{X}$}

\section{SYSTEMATIC BOTANY}

IN the early days of the science nearly every botanist's energies were devoted to that branch of it which we now call systematic botany. This is very natural, for the first stage in the attack on a mass of unknown things is to arrange and name them for ready reference. Linnæus was the first to bring some order out of the chaos, and to give all plants known to him names on a uniform system. He instituted the present binominal nomenclature, in which every species has a generic name (corresponding to a surname) and a specific name (corresponding to a baptismal name) in the form of an adjective, either in Latin or latinised modern language. In making the genera and arranging them in families attention is only paid to the floral organs, and plants are classified according to the number and position of the parts that make their flowers, cones, or sporebearing organs. In a genus itself, however, the different species are often distinguished by some vegetative characters, such as the hairiness or shape of the leaves or the habit of the stems.

Species when named had to be described so that other workers should not give the same plant another name, and, as it has always been very difficult to describe in words the minute details of any object, these descriptions were found to be very much more serviceable when accompanied with a drawing or figure of the 
described new form. Thus the descriptive floras were the most important part of the literature of the earlier botanists. These and the dried herbaria were, and are, to the botanist what the card index is to the librarian in a huge library. By now most of the species in the inhabited countries are known, but there still remain very many unrecorded species to reward any traveller and careful observer. There are named and described close on a quarter of a million of living species of plants altogether, including the lower and often nearly invisible forms, and of this vast number about one hundred and thirty thousand belong to the highest group of all - the Angiosperms. This fact acquires a further interest when we remember that this group has evolved in such comparatively recent geological times.

Botany has often been classed with stamp collecting in the older days when the only object of many who went under the name of botanist was to collect and name all the plants of their district, and when the naming of a new species was the ultimate crown of success. It is true that there have been many such in the rank and file of the adherents of the science, but one of the remarkable things about the great systematic botanists of the old school is the insight they obtained into the relations of the innumerable species they described. They not merely labelled and arranged the chaos, they classified the genera into families and cohorts which indicate the scheme of evolution, if not in all its details, at least in its main outlines.

The living plants may be divided into five main classes according to the complexity and structure of their reproductive organs. This is paralleled in the main by their vegetative structure, so that in general one can recognise a Seaweed, a Moss, a Bracken fern, 
a Pine tree, and a Rose as belonging to different grades; and that, for instance, a Toadstool, a Liverwort, a Hartstongue fern, a Yew tree, and a Lily form a similar series.

These series of plants each represent the five principal groups into which systematists have divided the families. The scientific names of these groups are the Thallophyta, the Bryophyta, the Pteridophyta, the Gymnosperms and the Angiosperms. In addition to these, there are one or two important kinds of plants which existed in past time, but which have since become extinct. Of these the Pteridospermæ, mentioned already in the chapter on Palæontology, lie between the pteridophytes and the gymnosperms.

Each of the five main groups are divided into a number of divisions, sometimes called phyla, each of which is composed of several families.

The Thallophyta have the largest number of species after the Angiosperms, and number about eighty thousand species all told. They are all comparatively simple in structure and have no differentiation into true leaves, stems, and roots, and have no woody or true vascular tissue. They have only spores and no seeds, but some of them have an alternation of generations. In this case, in one generation reproduction is by simple spores, and in the second it is by means of a spore resulting from the fusion of two sexual cells. This is not at all regular, however, and in many cases it depends on the nutrition and other conditions, which method of reproduction results. A large number of the Thallophyta never produce other than the simplest spores. A great proportion of these forms are very small and simple and live in the protecting medium of water. Such are all the small green algre of the ponds and streams, all the seaweeds, red, green, and brown, 
and a number of fungi. The Thallophyta include also the large fungi, the toadstools, and all the parasitic and disease-producing forms mentioned in the preceding chapter.

The Bryophyta form a much smaller group, reported to have about sixteen thousand species. Some of these appear, as do the mosses, to have true leaves, but their apparent leaves are not really homologous with those of the higher plants. They have some differentiation of conducting cells in the tissue, but no true wood or vessels. They have a definite alternation of generations, but the spore-producing generation grows on to the "leafy" sexual generation, and is generally, but wrongly, called its "fruit capsule." To this group belong all the Mosses and Liverworts, and between them and the rest of the cohorts there is one of the greatest gaps in the whole plant world. We have no elue to the course of their evolution, and no definite idea as to their relation to the other groups. It is evident, however, from their structure that they are less highly organised than the succeeding group of the Pteridophyta. This group, which makes so much more general impression on the landscape than does the preceding one, does not include so many as five thousand species altogether. All its members have a well-marked differentiation into leaves and stems, some with large leaves like the Bracken fern and some with small leaves like the Club-moss. All are provided with well-differentiated wood and phlœm, which are arranged in bundles in the stem, but none of the living forms have those zones of secondarily formed wood which is characteristic of the present higher plants and of the fossil pteridophytes. All the members, also, have a well-marked alternation of generations, but it differs from that of 
the bryophytes, for the leafy plant which is conspicuous is the spore-producing generation, while the sexual generation is a very small and inconspicuous little structure, as simple as an alga except for its sexual organs. To this cohort belong all the ferns, all the Equisetums or Horsotails, and the Club-mosses and Selaginellas. These three types of pteridophytos are separated into different phyla, for they differ in a number of important respects, and their fossil representatives add some further families to the group, but they all agree in the essentials enumerated for the group as a whole. In modern plants we have again a great gap, and then come the Gymnosperms. This gap is bridged by the fossil Pteridosperms. The gymnosperms have all a well-marked differentiation into roots, stems, and leaves, and all have differentiated wood and phlœm. Most of them grow to a considerable size, and have strong, woody trunks with zones of secondary wood. They all have complex fructifications with seeds, and in most cases these are borne on special leaves or branches, which often form a cone. The male cells are produced in pollen which is borne by small separate cones. To this group belong the Pine and Fir trees, the Yews, Cedars, Larches, and the Spruce, as well as the sub-tropical and comparatively rare Cycads. Of these there are not more than a total of about five hundred species, though in many districts, owing to their large size and their numbers in the forests, they appear to be the most important plants of the districts, as in the spruce forests of Canada or the pine belt of the continental mountains. The last and greatest group, the Angiosperms, with over a hundred and thirty thousand species, contains nearly all the plants that yield crops of economic importance to man, or that decorate his gardens, or that 
foed his sheep or cattle. Nearly all have highly difforentiated organs, with wood and vessels more differentiated than in the other groups. The majority of them have zones of secondary thickening, and all have the reproductive organs on special leaves, generally arranged together in "flowers," most of which are brightly coloured and ornamental. To many collectors this group alone constitutes the "flora" of a district, and the number of families it comprises is in proportion to the huge number of species it includes. When this group is further examined, there are found to be two well-marked divisions of it called the Monocotyledons and the Dicotyledons. The first has embryos with only one cotyledon or " seed leaf," the second has embryos with two. In the first group the leaves are generally long and narrow and have parallel veins, while the stems do not have secondary wood; in the second group the veins are reticulate, and the ring of primary bundles augmented by secondary thickening. To the former belong the Grasses, Palms, Lilies, and Orchids, and to the latter all the leafy trees like the Oak, Beech, and Maple, the majority of crops such as the Cabbage, Peas, and Strawberries, and flowers such as the Rose, Daisy, and Clematis. The families in both the two groups are separated principally according to the numbers of the parts in the flowers, and the relative positions of these parts which, on the whole, seem to bring together the species which are truly like each other. Speaking generally, one may say that there is a preponderance of four or five, or multiples of these numbers, in the flower parts of the Dicotyledons, with an almost universal appearance of three or its multiples in the flower of the Monocotyledons. The details of the classification of the families will be found in any flora, 
where the species are all described and where keys are provided so that any unknown plant can be identified and named.

With nearly a quarter of a million described forms to deal with the value of such keys will be recognised. Let us take an imaginary instance to illustrate the course of procedure with a new species. Let us imagine that in the English woods a plant very like a violet is found, but that, instead of the plain purple petal of the ordinary woodland species, it has a white fringed edge with red spots on its veins. Its flower would therefore resemble in some degree an orchid, and the finder would at once examine it to see whether it is a new violet or an orchid. We will imagine its leaves, however, to be similar to those of the ordinary violet except for a red streak down the main nerves. They would thus have network veins, which would at once separate the plant from the Monocotyledonous orchids. This, too, would be indicated by the five petals and the structure of the ovary. Let us imagine that the flower differs in no particular from the ordinary violet except in the points mentioned. Reference to an English flora would soon show that it is at any rate a new species for this country, but it may have been an "escape" from some garden to which it has been brought from some foreign country. The next thing to do is to look at the leading continental and American and other floras in the family of Violacoxe for the different parts of the world. These can all be seen at the British Museum. If such a plant is not described in any of them, it still does not prove that it is an unknown and therefore a new species. New plants are described in such numbers that they are not all incorporated in the current floras, and it might well be that it had been published in the transactions 
of some learned society, and not yet reproduced in the published general floras. To discover this, application would have to be made to some specialist at Kew or the British Museum. If the plant is unknown to them it is almost certain to be really a new species. The discoverer is then at liberty, indeed it is his duty, to describe and publish figures of it, and with this original description it must be named. Now, as we saw at the beginning, this imaginary flower is so like the violets that it must not be put in the genus Viola. The species name should be selected to give some indication of the nature of the plant. The red-veined leaves and the red spots along the petal nerves are very characteristic, and so a good name would be rubrinervis. In the future the violet would be known as Viola rubrinervis Smith, after the Mr. Smith we can imagine having discovered and described this new flower. In giving the species a name one most important point must be observed, and that is that no other Viola from any part of the world has that same species name. The confusion this would cause is obvious, and so one of the strictest rules followed by all systematists is that no new plant shall have a name already appropriated by another in the same genus, and if, unwitting, an author gives such a name, it shall immediately be superseded and renamed. To assist botanists in this there is a monumental work called the Index Kewensis, in which all the specific names ever given to plants are recorded with all their synonyms.

New species may merely swell the numbers of new forms known to systematists, or they may be important clues in the incomplete scheme of evolution. Sometimes in the latter sense some of the numerically smaller families are of the greatest interest. For instance, 
the plant known as Ginkgo biloba has no fellow-species in its genus, but is a single species composing a genus, and that genus by itself composes a family, and there are good grounds for putting that family in a phylum by itself. Thus, one single species by itself can form a whole phylum of plants, while in other cases there may be a thousand species or more in a phylum. In such a case that single species is obviously of greater interest and importance than one of the thousand. In the case of the Ginkgo just mentioned the reproductive organs have some unusual features, of which the most striking are the motile sperms, which swim like infusoria in a drop of water and are found in none of the higher families of plants but Ginkgo and the Cycads, and are similar to those in the ferns. The genus is interesting also in being the only representative left alive of a once large and widespread group. To the philosophical systematist, therefore, all his species are not of the same value, but all must be registered with equal care. The correct registering of the known plants of the world is the first duty of systematists - a knowledge of their inter-relations and phylogeny the greatest result of their work. 


\section{CHAPTER XI}

\section{CONCLUSION}

Wr have now surveyed, not in the details of fact but in the outline of fundamental principles, the field of modern botany. We see that it is no narrow and restricted subject, dry as the herbarium plants which used long ago to symbolise it. It is full of living interest, ramifying in many directions; it comprises branches technically distinct and requiring considerable knowledge and dexterity to pursue, all of which are combined and held together by the main philosophical principles that underlie the whole.

The really essential study in modern botany may be summed up in the phrase that it attempts to discover how plants live and how they came to be alive. Each branch of the subject described in the preceding chapters bears on these two problems. The systematist doscribes and arranges the plants now living, and, in conjunction with the palæobotanist, those also of the past. When they are in order it is seen how they grado themselves, and the question arises whether this series, from simple to complex, represents the order in which they appeared on the earth, and whether the systematist's classification corresponds to a more or less complete genealogical tree. The palæobotanist partly answers this question in the affirmative, but at the same time still further amplifies it, and discovers new questions 
with the unknown forms which he unearths. On the other side of the systematist stands the experimentalist, with his hybrids, varieties, and mutations, and offers a warning against holding any species as an immutable thing. A reminder that all the binomially named species in our text-books and floras are established only in a relative sense, for, since man's history began, new forms have arisen and taken their place in the ranks of those which "breed true," and therefore should be considered true species. From these branches of botany we get, if not cut and dried ideas on evolution, at least suggestive and stimulating ones. The morphologist, anatomist, and physiologist are chiefly concerned with the question of how plants live to-day, and the manner in which their mochanisms are adapted to the conditions in which they find themselves, and the way the delicate machine is balanced and adjusted. These living individuals the ecologist sees in communities, with inter-relations between the different members and adaptations to their conditions of environment. The results from all these studies again reflects light on the problems of the palæobotanist, for the plants of the past were also individuals, breathing, assimilating, with organs differing only in details from those of modern plants; and they also lived in communities. This works out like a sum in algebra with an unknown factor, for of the fossils there are only the anatomical and morphological features left, while of living plants these are available combined with experimental work on their physiological and ecological bearings. The relation between these being discovered in modern plants we can draw the conclusions about the conditions of the past oommunities. Here not many details have yet accumulated, but the work promises well, and it opens 
the door to knowledge of past continents that have vanished with their floras.

With the actual origin of plant life botanists would gladly deal had they any data. That is hid in the entirely impenetrable past however, and we return to the study of the present flora as it is represented in the simplest Thallophytic forms which still multitudinously inhabit the earth. It is probable that there we see the comparatively unchanged descendants from the simple forms which were among those which early inhabited the waters. Still, to-day there are some which have such a mixture of the characters of both plants and animals that it is almost impossible to say to which group they belong. Here we see, as we noticed in the cytological study of the most complex process, in the highest plants and animals an extraordinary unity botween the two great branches of the tree of life. 


\section{SUGGESTED COURSE OF READING}

\section{Text Books}

Stopes, M. C.-The Study of Plant Life. 2nd ed. Blackio, 1910. A simply written general text-book of botany for beginners. Scotr, D. H.-An Introduction to Structural Botany.

Part I.- " Flowering Plants." Black, 1909.

Part II._" Flowerless Plants." Black, 1907.

A detailed account, including the internal structure, of a sample type from each of the important plant groups, suitable for those beginning the serious study of botany.

StrasbURGer, E.-Text-book of Botany. Translated from the German. Macmillan, 1908.

A comprehensive text-book of university standard.

\section{General Books}

Butreson, W.-Method and Scope of Genetics. Inaugural lecture. Cambridge, 1908.

A semi-popular lecture on the subject of plant-breeding, \&c. Baterson, W.-Mendel's Principles of Heredity. Cambridge Press, 1909. An advanced, well-illustrated book, dealing with heredity in both plants and animals.

BowEr, F. O.-The Origin of a Land Flora. Macmillan \& Co. 1908. An advanced book, nevertheless written in a popular way, well illustrated.

Clements, W.-Research Methods in Ecology. U.S.A., 1905.

A treatise on ecology in which many new suggestions are made. Connow, E. T.-Plant Galls of Great Britain. Adlard, 1909.

Profusely illustrated account of insect-caused deformities. The Encyclopcedia Britannica, articles on the various branches of botany. See first the article "Botany," in which reference is made to the others. Cambridge University Press. 11th ed., 1911. Karner, A. and OrIver, F. W.-The Natural History of Plants. Vols. i. and ii. Blackie, 1894. Still the best and most delightful general account of plant biology. Well illustrated. 
Massiri, G.-Diseases of Cultivated Plants and Trees. Duckworth, 1910.

A well-illastrated, teohnical account of plant diseases.

SACHS, J. voN.-History of Botany (1530-1860). English edition. Oxford Press, 1890.

A very delightful book on the early history of botany.

SOHIMPER, A. F. W.-Plant Geography on a Physiological Basis. English translation. Oxford, Clarendon Press, 1903.

A finely illustrated account of the biology, ecology, and distribution of plants.

Scotr, D. H.-The Evolution of Plants. Williams \& Norgate, 1911.

A popular account, primarily dealing with evidence from the fossils.

Scort, D. H.-Studies in Fossil Botany. Vol. i. 2nd ed. Black, 1908. Vol. ii. 2nd ed. 1909.

An advanoed text-book, giving a detailed account of fossil plant anatomy.

Srward, A. C. - Links with the Past in the Plant World. Cambridgo University Press, 1911.

An essay on some plant families, principally gymnosperms and their ancestors.

Stopes, M. C.-Ancient Plants. Blackie, 1910.

A simple general account of fossil plants.

TANBLEY, A. G.-British Vegetation.

Types of British Vegetation. Cambridge University Press, 1911. The combined work of the English Ecologists, and the first attempt to present the native flora ecologically. Well illustrated.

Vrares, S. H.-Lectures on the Physiclogy of Plants. Cambridge Press, 1886.

A rather advanced text-book very pleasantly written.

Di VRIss, H.-Plant-Breeding, Comments on the Experiments of Nilsson and Burbank. 1907.

A profusely illustrated book, simply written.

W ARMrNa, E.-Ecology of Plants. English translation. Oxford, 1909. The original exposition of the subject, presented in English in a very readable form. 


\section{INDEX}

ADVENTITIOUS roots, 12

Algæ, 21, 30, 81

Ampelopsis, 16

Anatomy, 23

Angiosperms, $61,65,80,83$

Annual rings, 26

Araucaria, 62

BACTERIA, nitrogen-obtaining, in root nodules, 43 ; causing disease in plants, 76

Bast, 24

Biology, 7

Breathing of plants, 45

Breeding of plants, 68

Bryophyta, 81, 82

Bulbs, 14

Burbank, Luther, 70

Butcher's Broom, 13

CACTUS, 15, 52

Calamites, 63, 65

Callus formation, 74

Carbohydrates, in nutrition, 41

Carbon assinailation, 42

Carpel, 17, 19

Casts, fossil, 60

Cell, structure, 32

Chlorophyll, 25, 42

Chloroplasts, 42

Chlorosis, 75

Chromosomes, 35, 36

Classification of plants, 79

Club-moss, 64, 82, 83

Coal measures, fossil plants of, 63

Communities of plants, 50

Cordaites, 63

Corolla, 17

Creepers, 16

Cross-breeding, 69

Cuscuta, 21, 77

Cycads, 62, 83, 87

Cytology, 32
DARwIN, Charles, 70

Dicotyledons, 28, 30, 84

Discidia, 17

Diseases of plants, 74

Dodder, 21, 77

Drosera, 16

ECOLOGY, 50

Embryo, 19

Epidermis, 24

Equisetaceæ, 29

Equisetum, 65, 83

FASCIATION, 78

Ferns, 20, 28 ; fossil, 65

Ficus, 12

Flower, 10, 17, 69, 84

Fossil plants, 29, 58

Fruit, 19

Fungi, 21; causing disease in plants, 76

GALLS, 77

Geological systems, fossil plants in, 61

Geotropism, 47

Ginkgo biloba, 87

Gravitation, influence on plants, 47

Growth of plants, 40

Gymnosperms, 28, 65, 81, 83

HеАTH, 51

Heliotropism, 46

Heredity, 70

Horse chestnat, 15

Hybrids, 69

Hypertrophy of plant organs, 78

IDENTIFICATION of plants, 85

Impressions. fossil, 60

Index Kewensis, 86

LAMINARIAS, 30

Larkspur, 18

Leaf, 10, 13, 14, 27, $41,44,52,84$

Leguminacer, root nodules in, 43 
Lepidecorpon, 61 :

Lepidodendron, 63

Light, influence on plants, 46

Liverworts, 82

Lycopodiaceæ, 29, 64

Lycopodium, 64

Manarove, 12

Marsh, 51

Mendel, 70 ; Mendel's law, 70

Mineral salts, in nutrition, 42

Monkey-puzzle, 62

Monocotyledons, 11, 84

Moor plants, 51

Morphology, 10

Mosses, 21, 30, 82

Mutants, 73

NITrogen, in nutrition, 42

Nucleolus, 35

Nucleus, 32 ; mitosis of, 36

Nutrition of plants, 40,76

Denothera, 73

Origin of plant life, 90

Ovule, 18, 19

Paleobotany, 58

Palæontology, 58

Pathology, 74

Parenchyma, 24, 33

Peach curl, 77

Petals, see Flower

Petrifactions, 60

Phlœem, 24

Physical conditions, influence on plant growth, 52, 59 ; influence of plants on, 51

Physiology, 40

Pinguicula, 16

Pitcher plant, $\mathbf{1 6}$

Plant breeding, 68

Poisoning of plants, 75

Pollen, 17, 18, 69

Polytrichum, 30

Pond plants, 55

Potato rot, 77

Primrose, Evening, 73

Prop (aerial) roots, 12

Prothallus, 20
1. Protoplasm, 32

Psamma, 54

Pteridophyta, 29, 30, 64, 65, 81, 82

Pteridospermæ, $30,65,66,81,83$

RAFFLESIA, 22

Reproduction of plants, 18, 68

Rhododendron, 18

Root, 10, 11, 24

Rubus, 68

Ruscus, 13

Rushes, 55

SALT-MARSH plants, 53

Sand plants, 54

Scales, modified leaves, 15

Sclerenchyma, 24

Seashore plants, 54

Sedges, 55

Seed, 18, 19

Selanginella, 64, 83

Soil, influence on plant growth, 52

Sporangia, 10, 17

Stamen, 18, 19

Stem, 10, 11, 12 ; modifications

of, 13 ; anatomy of, 24

Stonecrop, 52

Sundew, 16

Swamp plants, 53

Sweet-pea, 16

Swellings, a bn ormal, in plants, 77

Systematic botany, 79

TEMPERATURE, influence on plants, 48

Thallophyta, 81

Thallus, 21

Transpiration current, 45

VASCULAR tissue, 24

Viola, 86

de Vries, Hugo, 72

WATER, circulation in plants, 44; modification of plants due to water supply, 52; water plants, 55

Wood, 24, 44

Woodland plants, 50,54

Wounds of plants, 74 


\section{THE PEOPLE'S BOOKS}

\section{THE FIRST SIXTY VOLUMES}

The volumes now (February 1912) issued are marked with an asterisk. A further twelve volumes will be issued in April

\section{SCIFNCA}

I. Introduction to Science - • $\cdot\left\{\begin{array}{l}\text { By W. C. D. Whetham, M.A., } \\ \text { F.R.S. }\end{array}\right.$ 2. Embryology -The Beginnings of Life By Prof. Gerald Leighton, M.D. 3. Biology-The Science of Life . $\quad\left\{\begin{array}{l}\text { By Prof. W. D. Henderson, M.A., } \\ \text { B.Sc, }\end{array}\right.$ 4. Animal Life $\left\{\begin{array}{l}\text { By Prof. E. W. MacBride, D.Sc., } \\ \text { F.R.S. }\end{array}\right.$

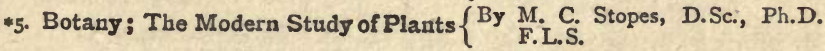
6. Bacteriology $\{$ By W. E. Carnegie Dickson, M.D., 7. Geology

8. Evolution.

9. Darwin 10. Heredity .

II. Chemistry of Non-living Things *12. Organic Chemistry *13. The Principles of Electricity

14. Radiation.

*15. The Science of the Stars . By the Rev. T. G. Bonney, F.R.S. - By E. S. Goodrich, M.A., F.R.S. \{ By Prof. W. Garstang, M.A., D.Sc., $\{$ F.Z.S.

- By J. A. S. Watson, B.Sc.

- By Prof. E. C. C. Baly, F.R.S.

- By Prof. J. B. Cohen, B.S.., F.R.S.

- By Norman R. Campbell, M.A.

- By P. Phillips, D.Sc.

$\{$ By E. W. Maunder, F.R.A.S., of the 16. Light, according to Modern Science By P. Phillips, D.Sc.

17. Weather-Science .

By G. F. K. Lempfert, of the Meteor-

19. The Baby: A Mother's Book by a \} By a University Woman.

20. Youth and Sex-Dangers and Safe- $\{$ By Mary Scharlieb, M.D., M.S., and guards for Boys and Girls . $\{$ G. E. C. Pritchard, M.A., M.D. 2I. Marriage and Motherhood-A Wife's f By H. S. Davidson, M.B., Handbook

22. Lord Kelvin . . . By A. E. Russell, M.A., D.Sc., 23. Huxley - • + . . By Professor G. Leighton, M.D. 24. Sir W. Huggins and Spectroscopic $\{$ By E.W. Maunder, F.R.A.S., of the Astronomy $\cdot \cdot \cdot \cdot\{$ Royal Observatory, Greenwich.

\section{PHILOSOPHY AND RELIGION}

25. The Meaning of Philosophy - . By Prof. A. E. Taylor, M.A. *26. Henrl Bergson: The Philosophy of Change By H. Wildon Carr.

27. Psychology • . + . - By H. J. Watt, M.A., Ph.D. 


\section{THE PEOPLE'S BOOKS}

\section{PHILOSOPAY END RELIGION-(continwed)}

28. Ethics

29. Kant's Philosophy.

30. The Teaching of Plato

38. Buddhism

32. Roman Catholicism

33. The Oxford Movement

34. The Bible in the Light of the Higher Criticism .

35. Cardinal Newman
(I)y the Rev. Canon Hastings Rashdall, D. Litt.

- By A. D. Lindsay, M.A.

- By A. D. Lindsay, M.A.

- By Prof. T. W. Rhys Davids, M.A. - By H. B. Coxon. Preface, Mgr. - By Wilfrid P. Ward.

By the Rev. Principal W. F. Adeney, M.A., D.D., and the Rev. Prof. W. H. Bennett, Litt. L., D.D. By Wilfrid Meynell.

\section{HISTORY}

36. The Growth of Freedom

37. Bismarck and the Foundation of the German Empire

38. Oliver Cromweil

*39. Mary Queen of Scots .

40. Cecil Rhodes .

4x. Julius Cresar: Soldier, Statesman, Emperor.

\section{History of England-}

42. England in the Making

By H. W. Nevinson.

By Prof. F. M. Powicke, M.A.

43. Medieval England.

44. The Monarchy and the People.

45. The Industrial Revolution .

46. Empire and Democracy
- By Hilda Johnstone, M.A.

- By E. O'Neill, M.A.

- By Ian Colvin.

\section{SOCIAT AND ICONOMIC}

*47. Women's Suffrage-A Short History of a Great Movement .

By M. G. Fawcett, LL.D.

48. The Working of the British System of Government to-day. By Prof. Ramsay Muir, M.A.

49. An Introduction to Economic Science By H. O. Meredith, M.A.

50. Socialism.

\section{LETTERS}

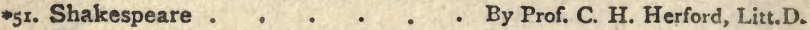

52. Wordsworth . . . . . By Miss Rosaline Masson.

*53. Pure Gold-A Cholce of Lyrics and Sonnets By H. C. O'Neill.

54. Francis Bacon - . . . By Prof. A. R. Skemp, M.A.

55. The Brontës . . . . . By Miss Flora Masson.

56. Carlyle . . . . . . . By the Rev. L. MacLean Wait.

457. Dante . . . . . . . By A. G. Ferrers Howell.

58. Ruskin . . . . . By A. Blyth Webster, M.A.

59. Common Faults in Writing English By Prof. A. R. Skemp, M.A.

60. A Dictionary of Synonyms . . By Austin K. Gray, B.A.

LONDON: T, C, \& E. C. JACK, 67 LONG ACRE, W.C. AND EDINBURGH 



\section{DAY USE}

\section{RETURN TO DESK FROM WHICH BORROWED}

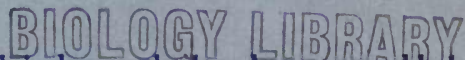

This book is due on the last date stamped below, or on the date to which renewed.

Renewed books are subject to immediate recall.

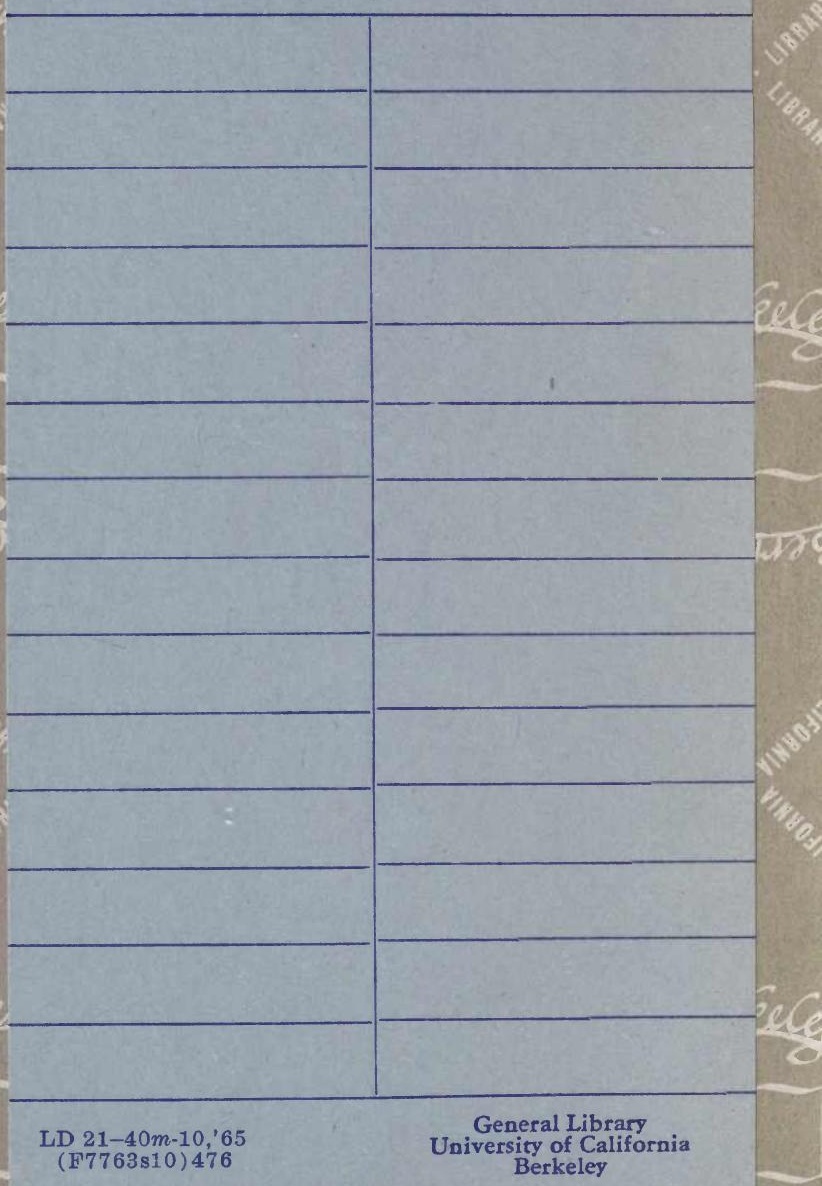




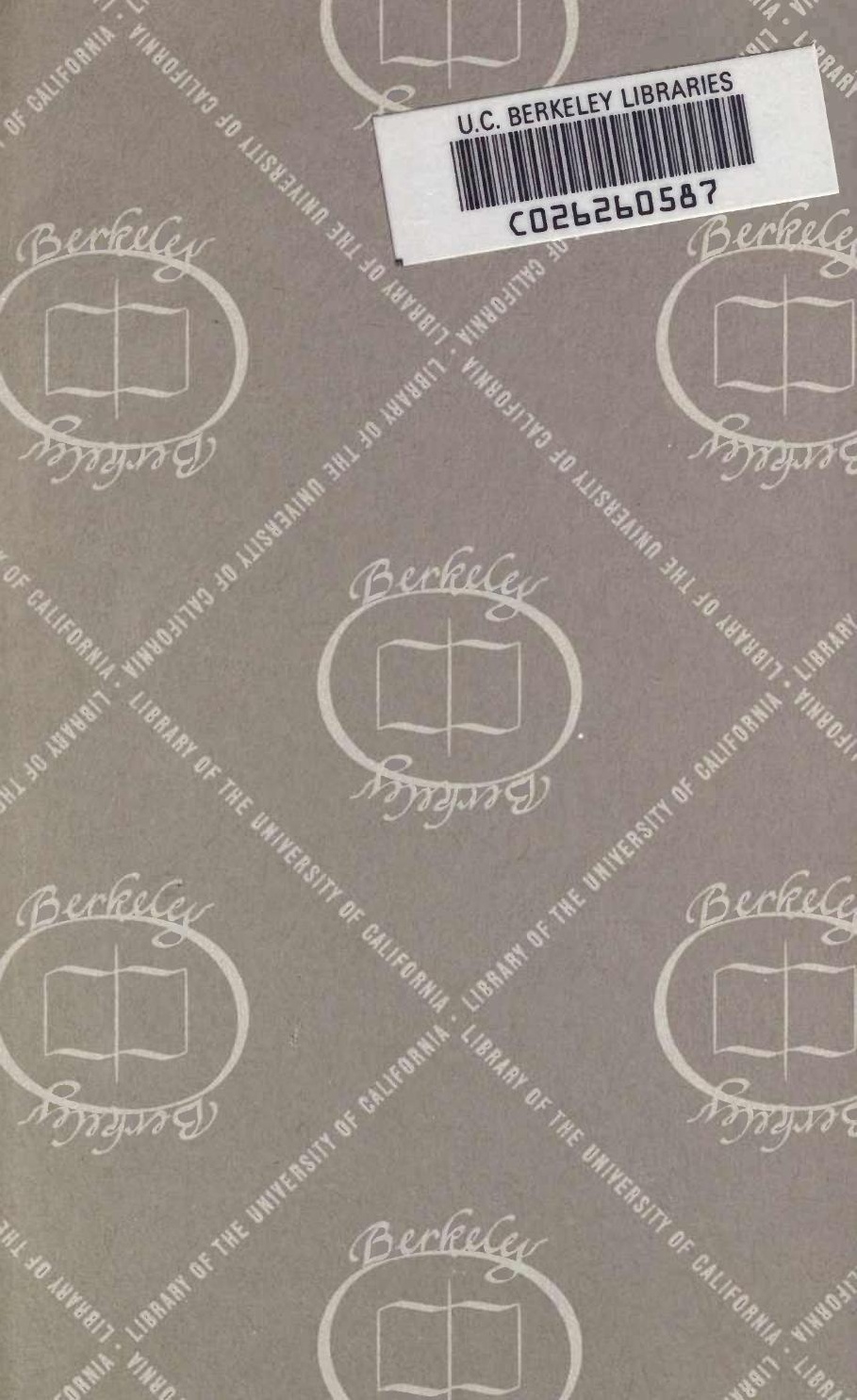


